\title{
Targeting Protein Quality Control Mechanisms by Natural Products to Promote Healthy Ageing
}

\author{
Sophia Wedel ${ }^{1}$, Maria Manola ${ }^{2}$ (D), Maria Cavinato ${ }^{1}$ (D), Ioannis P. Trougakos ${ }^{2, *}$ (1) and \\ Pidder Jansen-Dürr ${ }^{1, *}$ \\ 1 Institute for Biomedical Aging Research, University of Innsbruck, 6020 Innsbruck, Austria; \\ Sophia.Wedel@uibk.ac.at (S.W.); Maria.Cavinato-Nascimento@uibk.ac.at (M.C.) \\ 2 Department of Cell Biology and Biophysics, Faculty of Biology, National and Kapodistrian University of \\ Athens, 15784 Athens, Greece; mmanola@biol.uoa.gr \\ * Correspondence: itrougakos@biol.uoa.gr (I.P.T.); Pidder.Jansen-Duerr@uibk.ac.at (P.J.-D.)
}

Received: 13 April 2018; Accepted: 13 May 2018; Published: 19 May 2018

\begin{abstract}
Organismal ageing is associated with increased chance of morbidity or mortality and it is driven by diverse molecular pathways that are affected by both environmental and genetic factors. The progression of ageing correlates with the gradual accumulation of stressors and damaged biomolecules due to the time-dependent decline of stress resistance and functional capacity, which eventually compromise cellular homeodynamics. As protein machines carry out the majority of cellular functions, proteome quality control is critical for cellular functionality and is carried out through the curating activity of the proteostasis network (PN). Key components of the PN are the two main degradation machineries, namely the ubiquitin-proteasome and autophagy-lysosome pathways along with several stress-responsive pathways, such as that of nuclear factor erythroid 2-related factor 2 (Nrf2), which mobilises cytoprotective genomic responses against oxidative and/or xenobiotic damage. Reportedly, genetic or dietary interventions that activate components of the PN delay ageing in evolutionarily diverse organisms. Natural products (extracts or pure compounds) represent an extraordinary inventory of highly diverse structural scaffolds that offer promising activities towards meeting the challenge of increasing healthspan and/or delaying ageing (e.g., spermidine, quercetin or sulforaphane). Herein, we review those natural compounds that have been found to activate proteostatic and/or anti-stress cellular responses and hence have the potential to delay cellular senescence and/or in vivo ageing.
\end{abstract}

Keywords: autophagy; proteasome; proteostasis network; natural products; Nrf2

\section{Introduction}

The viability of metazoans largely depends on their ability to regulate metabolic processes in order to generate biomolecules [1]. In eukaryotic cells these molecules are produced in mitochondria through the action of a protein machinery that drives the oxidative phosphorylation (OXPHOS) [2]. During this process, reactive oxygen species (ROS) are formed as by-products [3]. Free radicals and their derivatives are highly reactive molecules and, in physiological concentrations, are essential for proper intracellular signalling, metabolism and responses to pathogens. If their concentration exceeds the cellular antioxidant capacity, however, they cause oxidative stress and damage to all cellular biomolecules [4]. In addition to mitochondria, ROS are also produced by NAD(P)H oxidases, xanthine oxidase and nitric oxide synthase, and may also arise from exogenous sources such as atmospheric pollutants, ultraviolet (UV) light, X- or gamma-rays [3-5].

Organisms maintain a proper supply of energetic molecules and retain low levels of stressors or damaged biomolecules via the action of a complex quality control system [6]. At the proteome 
level, this process is largely achieved via the action of the highly integrated and modular proteostasis network (PN) [7-10]. During the ageing process, cellular functions deteriorate and compromise these mechanisms, resulting in the impairment of signalling, repair and clearance pathways [11]. This promotes the gradual accumulation of stressors, which correlates with increased disability, morbidity and inevitably death [11,12]. In accordance with this view, age is the major risk factor for several life-threatening diseases, including cancer, cardiovascular diseases, neurodegeneration and diabetes $[13,14]$. Interestingly, ageing can be delayed by either dietary [e.g., caloric restriction (CR)] or genetic interventions, which modulate stress-responsive pathways and thus affect, either directly or indirectly, the impact of stressors and the rate that damaged biomolecules accumulate [15].

Herein, we summarise the most recent findings related to natural compounds that reportedly delay cellular senescence and/or prolong in vivo longevity by activating cytoprotective proteostatic mechanisms and/or the nuclear factor E2-related factor (Nrf2) anti-stress pathway.

\section{Overview of the Cellular Proteostatic Modules}

Downstream to genetic information, there is a world of immense complexity and plasticity, namely the proteome. The entry point in this world occurs via ribosome-mediated protein synthesis that takes place in both the cytosol and the endoplasmic reticulum (ER). As the average proteome size has increased during evolution [16] and the consequences of an unstable proteome can be catastrophic [17], cells have evolved a system that ensures proteome stability, namely the PN [6]. The PN machinery comprises numerous chaperones, folding enzymes, trafficking and degradation components [6]. During conditions of proteotoxic stress, the PN determines the fate of damaged polypeptides by either folding, holding, or degrading [18].

The PN is regulated at organismal, tissue-specific and cellular level [10]. The protein synthesis module along with the machineries involved in sorting and trafficking of newly synthesised polypeptides are key components of the PN and they are complemented by the unfolded protein response of the ER (UPR $\left.{ }^{\mathrm{ER}}\right)$ and mitochondria $\left(\mathrm{UPR}^{\mathrm{mt}}\right)$, the intra- and extra-cellular molecular chaperones and a number of compartmentalised proteases, along with the two main degradation branches, i.e., the ubiquitin-proteasome system (UPS) and the autophagy-lysosome (ALP) pathway $[9,10,19,20]$.

A number of short-lived transcription factors are also considered to be part of the PN as they mobilise genomic cytoprotective responses [21]. These, among many others, include heat shock factor 1 (Hsf1), which regulates the levels of molecular chaperones [22]; forkhead box O (FoxO), which promotes antioxidant and metabolic genomic responses [23], and Nrf2, which responds to oxidative, electrophilic, and/or proteotoxic stress [24].

Deregulation of the PN functionality is associated with ageing and it is considered a major risk factor for a wide spectrum of age-related protein conformational diseases such as immunological and metabolic disorders, cardiovascular and neurodegenerative diseases and cancer $[8,25,26]$. Moreover, loss of proteostasis is recognised as a hallmark of ageing, indicating the great significance of the PN in cellular functionality and survival [27]. Additionally, several studies have revealed that the activation of proteostatic modules by genetic, dietary (e.g., CR), and/or pharmacological interventions increases organismal health- and/or life-span and delays cellular senescence [15]. For example, UPS activation is able to delay ageing in numerous cellular models [9]. Also, genetic activation of the $20 \mathrm{~S}$ proteasome leads to lifespan extension and increases stress resistance in the nematodes Caenorhabditis elegans [28].

\section{The Ubiquitin-Proteasome System (UPS)}

The UPS degrades short-lived, poly-ubiquitinated normal proteins and non-functional or misfolded polypeptides. Ubiquitinated polypeptides are degraded by the $26 \mathrm{~S}$ proteasome, while non-native (e.g., oxidised) polypeptides are likely degraded by the $20 \mathrm{~S}$ proteasome via chaperone-mediated targeting [29]. The ubiquitin-proteasome system is composed of ubiquitin-activating, conjugating and ligating enzymes and the 26S proteasome [9]. The 26S eukaryotic 
proteasome is a protein machine of $\sim 2.5 \mathrm{MDa}$ that is composed of a $20 \mathrm{~S}$ core particle (CP) to which one or two 19S cap regulatory particles (RP) are bound [30,31]. The 20S CP consists of four stacked heptameric rings (two $\alpha$-type surrounding two $\beta$-type rings) that form a barrel-like structure; the caspase- (C-L; LLE/ $\beta 1)$, trypsin- (T-L; LRR/ $\beta 2)$, and chymotrypsin- (CT-L; LLVY/ $\beta 5$ ) like peptidase activities are located at the $\beta 1, \beta 2$, and $\beta 5$ proteasomal subunits, respectively. The $19 S$ $\mathrm{RP}$ is involved in substrate recognition, deubiquitination, unfolding and translocation of proteins into the 20S CP [9].

The catalytic activity of the proteasome is central to quality control of protein synthesis as non-functional newly synthesised polypeptides originating from cytosolic or ER-bound ribosomes are targeted for degradation to cytosolic or ER-bound proteasomes [ER associated protein degradation (ERAD)] respectively [32]. Proteasomes are also found in the nucleus, where they participate in DNA damage response (DDR) processes and in the outer membrane of the mitochondria, where they execute outer mitochondrial membrane-associated degradation (OMMAD) during the activation of the UPR ${ }^{\mathrm{mt}}$ [33]. UPS is also involved in the degradation of mitochondrial fusion/fission proteins [2] and, thus, apart from genome and proteome stability, UPS functionality is also critical for mitostasis maintenance.

\section{Stress and Proteome Damage Responses: The Nrf2 Transcription Factor}

The various branches of the PN are functionally coordinated by different signalling cascades, which sense and respond to imbalances in proteostasis and/or increased amounts of stressors $[8,34]$. These signalling cascades are modulated by stress sensitive, short-lived transcription factors $[21,35,36]$.

As mentioned, one of the several proteins that comprise the network of stress-responsive cellular sensors is the transcription factor Nrf2, which plays a central role in cellular responses against oxidative and/or xenobiotic damage (Figure 1) [24]. Under physiological conditions, Nrf2 is a short-lived protein, because it is constantly targeted by Kelch-like ECH- associated protein 1 (Keap1) for Ub-dependent proteasomal degradation; parallel to Keap1, the Beta-transducin repeat-containing protein/glycogen synthase kinase-3 (b-TRCP/Gsk-3) axis can also mediate degradation, and thus inhibition, of Nrf2 [37]. In response to increased amounts of oxidants, the three cysteine residues Cys-151, Cys-273 and Cys-288 of Keap1 are oxidised leading to reduced Keap1-Nrf2 binding and consequently to reduced Nrf2 ubiquitination [38]. This event stabilises Nrf2, which then translocates from the cytosol to the nucleus to form a heterodimer with its partner v-Maf avian musculoaponeurotic fibrosarcoma oncogene homolog (Maf); the dimer binds to the antioxidant response elements (AREs) or electrophile response elements- (EpREs) of the DNA and regulates the expression of numerous genes [39,40]. The Nrf2 signalling pathway provides detoxification through the elimination of potentially harmful and toxic compounds or metabolism derivatives [24,41]. Reportedly, in higher metazoans, Nrf2 is also involved in the upregulation of UPS and ALP genes during proteotoxic stress [42-45]. 


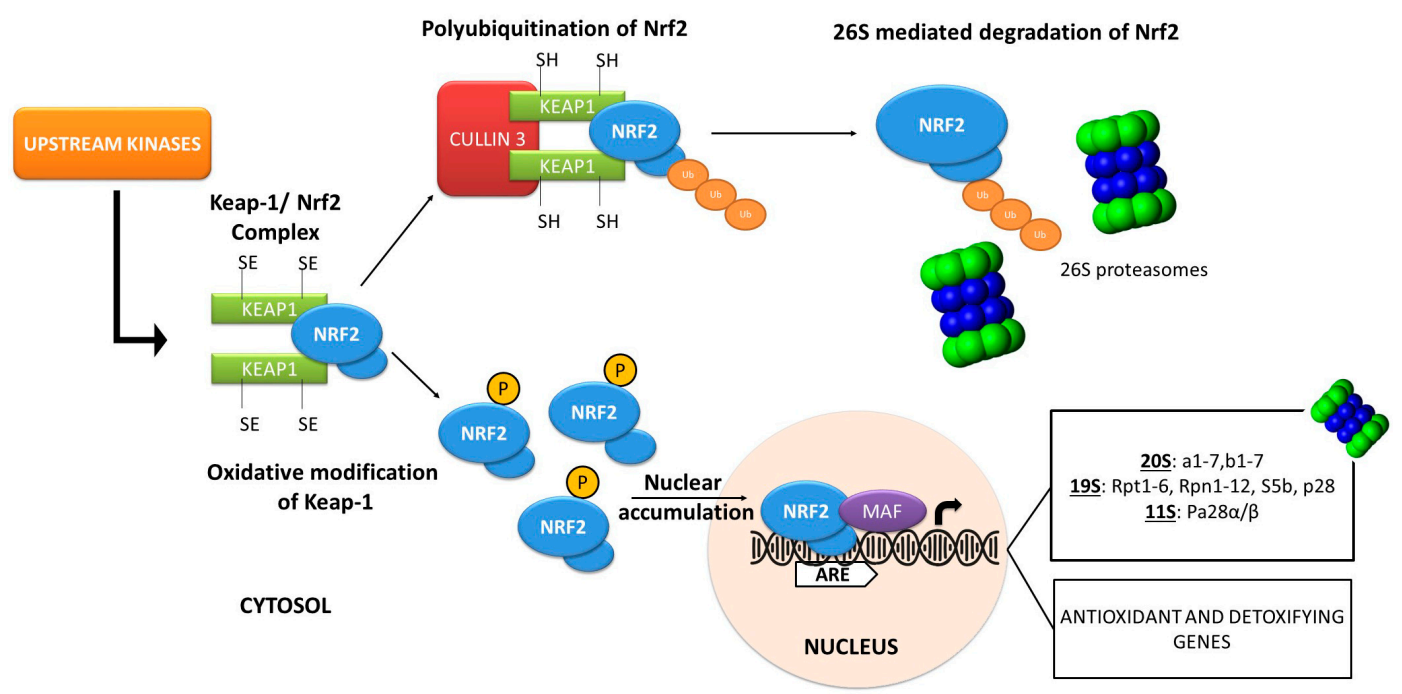

Figure 1. Schematic presentation of the pathways known to modulate Nrf2 activity. Under basal conditions, Nrf2 is poly-ubiquitinated and targeted for proteasomal degradation. Oxidative stress modifies Keap1 leading to Nrf2 stabilization and nuclear translocation. In the nucleus, Nrf2 activates a wide range of transcriptional targets including antioxidant and proteostatic genes. The Nrf2 activity can be also modulated by upstream kinases (e.g., Akt or Gsk-3).

\section{The Autophagy-Lysosome Pathway (ALP)}

The ALP is, next to the UPS, one of the two main cellular degradation and recycling mechanisms in eukaryotic cells [46]. Macroautophagy (hereafter referred to as autophagy) describes enclosure of cellular material in double-membrane vesicles, also known as autophagosomes, and subsequent fusion with lysosomes for degradation [47]. The process of autophagy can be summarised in five events, namely induction, nucleation, expansion, fusion and cargo degradation/recycling [46].

Cellular energy levels, as well as nutrients and growth factors, are major players in the regulation of autophagy since the primordial function of autophagy is to protect cells from starvation-associated stress [47,48]. mTOR (mammalian target of rapamycin), a serine-threonine kinase, is the main regulator of cellular metabolism and controls anabolic as well as catabolic processes in response to environmental stimuli [48]. Consequently, mTOR activity also influences autophagy regulation [49].

Downregulation of mTOR activity under conditions of nutrient deficiency or growth factor depletion results in the induction of autophagy [50]. mTOR forms two distinct complexes, mTORC1 and mTORC2 [48]. Repressed mTORC1 signalling activates the autophagy-initiating UNC-5 like autophagy activation kinase (ULK) complex, which includes ULK1/2, FIP200, autophagy-related gene 101 (ATG101) and the autophagy-related gene 13 (ATG13) [47]. ULK1/2 and ATG13 are targets of mTORC1 phosphorylation that renders them inactive. Upon mTORC1 inhibition, these molecules are not phosphorylated and ULK kinase activity is restored leading to the recruitment of the Vps34 complex to the phagophore, a double membrane intermediate [46,47]. The recruitment of Vps34 initiates the binding of other ATG proteins and the lipidation of LC3 [47]. Upon binding of ATG12 and LC3, the phagophore expands [46]. The autophagosomes are fused with lysosomes, initiating the last step of the autophagy process, in which the cargo is degraded by hydrolases and macromolecules are released back into the cytoplasm [46]. The molecular mechanisms of mTORC2 regulation are less well understood [48].

\section{Upstream Regulators of Autophagy-Lysosome Pathway}

As mentioned above, mTOR inhibition leads to activation of autophagy. Consequently, regulators of mTORC1 play a major role in autophagy regulation. The growth factor (GF)/phosphoinositide 3-kinase (PI3K)/protein kinase B (Akt) signalling pathway is a well-established upstream regulator of 
mTORC1 [48]. Activated Akt is able to repress the potent mTORC1 inhibitor TSC1/2, which means that if GF/PI3K/Akt signaling is active, also mTORC1 is active [51] (Figure 2).

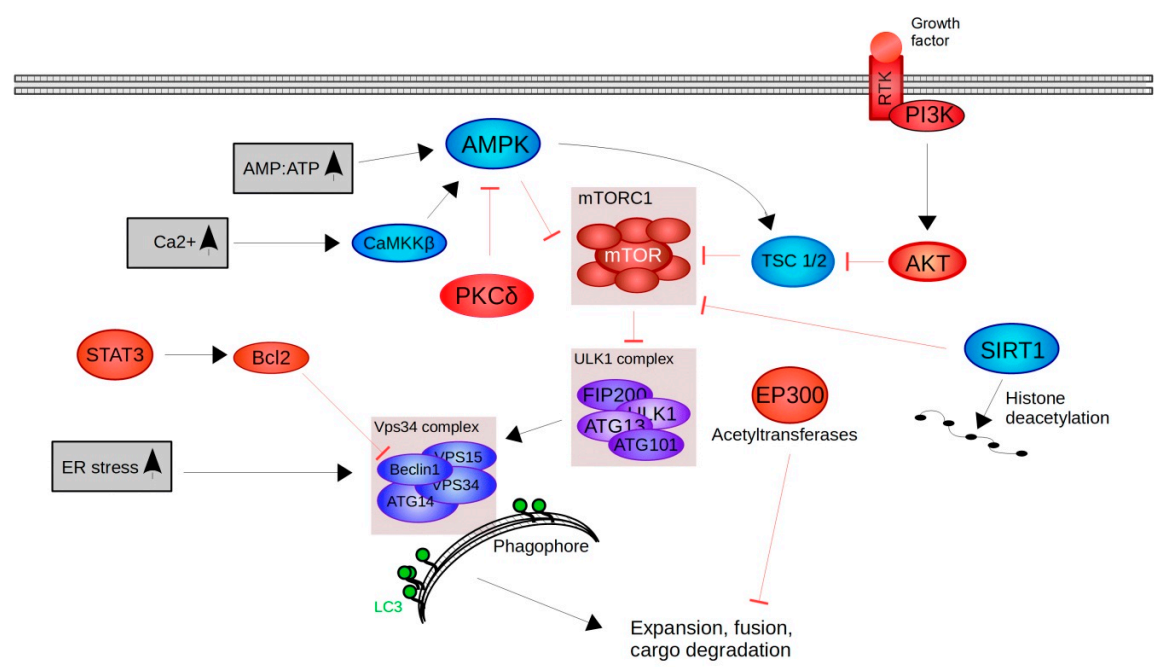

Figure 2. Mechanisms of autophagy-induction. The mTORC1 complex is a central regulator of autophagy-initiation. If active, mTORC1 inhibits the ULK1 complex and its ability to recruit the Vps34 complex to the phagophore. The binding of the Vps34 complex is essential for lipidation of LC3, autophagosome formation, fusion and consequent cargo degradation. Cellular stressors (shown in grey), such as ER stress, increasing intracellular $\mathrm{Ca}^{2+}$ levels and the shift of energy levels (increase of the AMP:ATP ratio) influences autophagy initiation either upstream of mTORC1 or directly at the Vps34 complex. Other positive regulators of autophagy (shown in blue) include SIRT1 and TSC1/2 signalling. Negative regulators of autophagy (shown in red) comprise PI3K/Akt, STAT3/Bcl2, PKC $\delta$ and EP300.

Another mTORC1 upstream regulator is AMPK, which is able to sense changes in cellular energy levels and is activated by increased AMP:ATP ratio [46]. Active AMPK phosphorylates and consequently inhibits mTORC1, stimulates TSC1/2 and activates ULK1 by direct phosphorylation [46]. In addition, $\mathrm{AMPK}$ is sensitive to intracellular $\mathrm{Ca}^{2+}$ levels via the calmodulin-dependent protein kinase kinase- $\beta(\mathrm{CaMKK} \beta)$. Increasing cytosolic $\mathrm{Ca}^{2+}$ levels activate $\mathrm{CaMKK} \beta$, which in turn stimulates AMPK signalling [52].

As mentioned above, the ER is a membrane-bound organelle responsible for post-translational modifications and the correct folding of secretory and/or membrane proteins [53]. Additionally, the ER is a key player in lipid biosynthesis, intracellular $\mathrm{Ca}^{2+}$ balance and energy metabolism [53]. If ER homeostasis is disrupted (referred to as ER-stress) unfolded or misfolded proteins begin to accumulate resulting in increased autophagic activity [53,54].

Another probable mechanism for autophagy induction is the signal transducer and activator of the transcription 3 (Stat3)/Bcl-2 pathway [55]. Stat3 upregulates the pro-survival gene Bcl-2, which is known to prevent cells from undergoing autophagy by directly binding to Beclin-1 [56]. Consequently, inhibition of Stat3/Bcl-2 in esophageal squamous-cell carcinoma cells has the opposite effect on Beclin-1 regulation and induces autophagy [55].

Sirtuins are members of a highly conserved family of $\mathrm{NAD}^{+}$-dependent (class III) protein deacetylases [57]. SIRT-1 deacetylates histones and non-histone proteins including transcription factors and consequently regulates a broad range of different pathways and cellular processes, such as cell survival, stress resistance and metabolism [58]. Distinct transcription factors affected by SIRT1 signalling are nuclear factor NF-кB, FoxOs and PPAR-gamma co-activator $1 \alpha(P G C 1 \alpha)$ [57]. This indicates that post-translational modifications, specifically acetylation and deacetylation of proteins, have the potential to regulate autophagy [50]. EP300, for example, acetylates and by this 
inhibits several autophagy-related proteins [59]. Hence, repressors of EP300 are considered to be autophagy regulating molecules [60].

Furthermore, protein kinase delta (PKC $\delta$ ) stimulates the expression of tissue transglutaminase 2 (TG2), which is known as a potent repressor of autophagy [61]. The PKC $\delta / T G 2$ axis affects other signalling pathways known for autophagy-inhibition, like mTOR, NF-kB and Bcl-2 [61]. Consequently, inhibitors of PKC $\delta$ have the potential to activate the autophagy machinery [51].

Evidence suggests that autophagy and ageing are correlated processes since the induction of autophagy seems to extend health- and lifespan, whereas autophagy deficiency accelerates ageing $[50,62]$. Therefore, the field of research around natural compounds, which are able to promote healthy ageing by manipulating UPS and ALP has gained interest. In the following sections, natural compounds that were found to activate proteostatic modules and to also delay cellular senescence and increase organismal healthspan and/or lifespan will be discussed in detail.

\section{Natural Compounds Found to Activate Nrf2, UPS or ALP}

Natural compounds that affect both the UPS and ALP activity are of particular interest. These bifunctional compounds are summarised in Table 1 and will be discussed in the following section.

Resveratrol(3,5,4'- trihydroxy-trans-stilbene) is a natural polyphenol that occurs in many plants including grapes, berries, knotweed and peanuts [63]. It was first isolated from the roots of Veratrum grandiflorum and has numerous beneficial effects on health such as anti-inflammatory, anti-oxidant and cytoprotective properties [58,64-66]. Resveratrol promoted longevity in Saccharomyces cerevisiae, Drosophila melanogaster, Apis mellifera and Caenorhabditis elegans, in the short-lived fish species Nothobranchius furzeri and Nothobranchius guentheri as well as in metabolically compromised (but not in healthy) mice [57]. This compound is also known for its potential to slow the progression of many age-related human diseases, such as some types of cancer, neurological disorders (e.g., Alzheimer's disease), cardiovascular diseases and diabetes [58]. Resveratrol induces autophagy through different signalling pathways, depending on the cellular and environmental context [51,65]. In a Parkinson's disease cellular model, of dopaminergic neuronal cell lines including SH-SY5Y and PC12 cells, $24 \mathrm{~h}$ treatment with $50 \mu \mathrm{M}$ resveratrol promoted AMPK phosphorylation at Thr-172, inhibition of mTOR and also activation of SIRT1 [67]. These mechanisms ultimately contribute to the induction of autophagy [67]. Similar results were achieved in an Alzheimer's-disease model (APP-HEK293 cells), where a $72 \mathrm{~h}$ treatment with $40 \mu \mathrm{M}$ resveratrol-induced phosphorylation of AMPK at Thr-172 via the $\mathrm{Ca}^{2+} / \mathrm{CaMKK} \beta$-dependent mechanism. Park et al. [68] recently reported that resveratrol inhibited mTOR function by an ATP competitive mode of action in different cancer cell lines. In this study, it was suggested that resveratrol binds directly to the mTOR ATP-binding site and thereby inhibits the complex's signalling and activates autophagy [68]. Apart from autophagy, two distinct studies on rat models revealed the Nrf2-activating ability of resveratrol. Oral administration of resveratrol in a rat model at a dose of $10 \mathrm{mg} / \mathrm{kg}$ of body weight improved antioxidant responses by activating the Nrf2 pathway along with SIRT1 and AMPK [69]. Moreover, treatment of diabetic rats with resveratrol at a dose of $20 \mathrm{mg} / \mathrm{kg}$ of body weight revealed that challenging the cells' redox balance, alternates the phosphorylation status and enhances the transcription of antioxidant enzymes. Changes in the regulation of gene expression were accompanied by the nuclear accumulation of the transcription factors Nrf2 and NF-kB [70].

Metformin, which derives from guanidine, and is found in Galega officinalis (Fabaceae) was reported to delay age-related loss of locomotion and lipofuscin accumulation, and to significantly extend median lifespan in C. elegans by $40 \%$, when administrated at a concentration of $50 \mathrm{mM}$. It was shown that the healthspan benefits of metformin could be mediated through the activation of the Skin1/Nrf2 transcription factor [71]. In support, Martin-Montalvo et al. [72] reported that metformin improved healthspan and lifespan in mice via the induction of the Nrf2-ARE pathway. In terms of human disease treatment, metformin is currently used as a first-line drug to treat diabetes type 2 [73]. Interestingly, metformin administration does not only affect diabetes mellitus type 2 but it 
also improves other clinical conditions, such as cardiovascular disease [74]. It was suggested that autophagy could be the mechanism underlying the reduction of diabetic cardiomyopathy $[55,75]$. AMPK phosphorylation at Thr-172 and consequent inhibition of mTOR signalling seem to be the key regulators in metformin-induced autophagy in melanoma cells [76]. As shown by Feng et al. [55] in esophageal squamous cell carcinoma, treatment with $10 \mathrm{mM}$ metformin for $48 \mathrm{~h}$ activated autophagy in an AMPK-dependent as well as in AMPK-independent manner. In this context, the AMPK-independent signalling pathway involves STAT3 inhibition; repression of Bcl-2 and therefore autophagy activation [55].

Curcumin (diferuloylmethane) is synthesised by Curcuma longa (also known as turmeric) and has antioxidant, anti-inflammatory, anticancer, neuro- and cardio-protective properties [77,78]. The treatment of Caenorhabditis elegans, Drosophila melanogaster and Mus musculus with curcumin proved the compound's potential to increase lifespan [79]. In these studies, the mean lifespan of Drosophila flies was extended by more than $10 \%$ via the addition of $0.5-1.0 \mathrm{mg} / \mathrm{g}$ of curcumin in the culture medium by suppressing oxidative stress and lipid peroxidation, reducing the accumulation of dialdehydes and improving locomotor performance; these health beneficial effects have been attributed to the modulation of a number of stress-responsive genes including the antioxidant enzyme superoxide dismutase [80,81]. At the molecular level, it was found that curcumin could upregulate the sirtuin pathway and strongly activated the Nrf2-ARE pathway in different tissues [82,83].

Additionally, it was demonstrated that curcumin (or its analogue bis-dehydroxy-curcumin) induced apoptosis via autophagy activation in various types of cancer cells including colon cancer, uterine leiomyosarcoma, ovarian cancer and lung adenocarcinoma [54,77,84-86]. Curcumin or its analogues, B19 or bis-dehydroxy-curcumin, were reported to induce autophagy either via the ER-stress mediated pathway, as shown in ovarian cancer cells [54] and colon cancer cells [84] by acting as an inhibitor of EP300 acetyltransferases in multiple cancer cells, or through mTOR inhibition, as shown in uterine leiomyosarcoma cells [87].

Genistein (4', 5, 7-trihydroxyisoflavone) is a natural polyphenol found in soy and other legumes, such as Vigna angularis, that reportedly extended the lifespan of Caenorhabditis elegans [88,89]. Skin anti-ageing effects have been accredited to this polyphenol, as it can bind to estrogen receptors, enhance collagen biosynthesis, act as an antioxidant and protect from UV-induced photodamage [88]. Additionally, the enrichment of rat diet with low doses of genistein demonstrated neuroprotective properties along with antioxidant and cognitive function preservation effects [90]. Genistein was found to enhance endothelial nitric oxide synthase (eNOS) activation; the Nrf2/HO-1 pathway via increased Keap1 S-nitrosylation as well as the nuclear accumulation and DNA binding activity of Nrf2 [90]. Genistein was also found to protect cerebrovascular endothelial cells from oxidative damage via the activation of the Nrf2-mediated stress response pathway by acting on upstream kinases such as PI3K [91]. Genistein induced autophagy in MCF-7 cells (100 $\mu \mathrm{M}$ genistein for $72 \mathrm{~h})$, as well as in ovarian cancer cells (100 $\mu \mathrm{M}$ genistein for $24 \mathrm{~h})$ [92,93]. This compound can affect numerous cellular processes, due to its potential to repress the activity of different protein-tyrosine kinases [93]. Consequently, genistein influenced PI3K-Akt signalling, which might contribute to a lower rate of glucose metabolism and hence, to a starvation-like autophagy induction in ovarian cancer cells [51,93].

Catechins are polyphenols synthesised by Camilla sinensis [94]. Catechins are known to exert antioxidant, anti-inflammatory and anti-angiogenic properties and have demonstrated beneficial effects in treating and preventing cancer, diabetes, obesity, neurodegenerative disease and cardiovascular diseases [95]. Furthermore, the cosmetic industry shows a growing interest in these polyphenols, since they have demonstrated skin anti-ageing effects [96]. Catechins and their derivatives were able to extend lifespan in Caenorhabditis elegans, Drosophila melanogaster and Mus musculus $[97,98]$. More specifically, Sucro-Laos et al. [99] and Sunagawa et al. [100] found that methylated epicatechin derivatives $(200 \mu \mathrm{M})$ prolonged the mean lifespan of $C$. elegans by $\sim 6-12 \%$, probably by modulating an energy-intensive, stress response and repair system [101]. Moreover, daily administration of epigallocatechin gallate (EGCG) $(55$ and $220 \mu \mathrm{M})$ in C. elegans prolonged the mean lifespan of the 
worm by $\sim 10 \%$. It also significantly decreased intracellular oxidative stress and formation of lipofuscin, most likely via the activation of the Daf16/FoxO signalling pathway [102,103]. In addition, both in vitro and in vivo studies found EGCG to induce Nrf2 expression exerting cancer chemopreventive properties [104] and protection against lupus nephritis [105]. EGCG has also demonstrated its protective effect on human umbilical vein endothelial cells from PM2.5-induced oxidative stress by upregulating Nrf2/HO-1 via the activation of the p38 MAPK and the extracellular signal-regulated kinase 1/2 (ERK1/2) signalling pathways [106]. Furthermore, Na et al. [107] found that EGCG induces Nrf2-mediated expression of manganese superoxide dismutase (MnSOD) and HO-1 and activated ERK1/2 and PI3K/Akt signalling in MCF10A cells. Moreover, EGCG was found to promote the dissociation of Nrf2 from Keap1 [108]; in support, Kanzaki et al. [109] demonstrated that sulforaphane and EGCG augmented the nuclear translocation of Nrf2 and HO-1 expression in a mouse monocytic cell line. Also, Yang et al. [106] reported that EGCG increased the Nrf2 nuclear translocation in a normal rat kidney proximal tubular epithelial cell line, namely NRK-52E.

Regarding autophagy, the action of catechins is ambiguous, concentration- and cell type-dependent [110]. For example, $100 \mu \mathrm{M}$ catechin blocks hypoxia/reperfusion-induced autophagy via increasing Akt/mTOR phosphorylation in microglia [111]. On the other hand, Kim et al. [112] showed that treatment with $10 \mu \mathrm{M}$ EGCG for $4 \mathrm{~h}$ induces autophagy through a $\mathrm{Ca}^{2+} / \mathrm{CaMKK} \beta /$ AMPK-mediated mechanism in endothelial cells. 
Table 1. Bifunctional natural compounds which influence proteasome activity and autophagy.

\begin{tabular}{|c|c|c|c|c|c|c|}
\hline Compound & Structure & Source & Model & Dose Used & Proposed Mechanism of Action & Reference \\
\hline \multirow{4}{*}{ Resveratrol } & \multirow{4}{*}{ nopor } & \multirow{4}{*}{$\begin{array}{l}\text { Grape, nuts and peanuts } \\
\text { Veratrum grandiflorum }\end{array}$} & Male Wistar Periodontitis rats & $10 \mathrm{mg} / \mathrm{kg}$ B.W. & $\uparrow$ Nrf2-mediated antioxidant response & [69] \\
\hline & & & Diabetic rats & $20 \mathrm{mg} / \mathrm{kg}$ B.W. & $\uparrow \mathrm{Nrf} 2$ nuclear translocation & [70] \\
\hline & & & SH-SY5Y cells & $50 \mu \mathrm{M}-24 \mathrm{~h}$ & $\begin{array}{l}\text { AMPK } \\
\text { SIRT1 }\end{array}$ & [67] \\
\hline & & & Various cancer cell lines & $50-100 \mu \mathrm{M}-2-4 \mathrm{~h}$ & mTOR direct binding & [68] \\
\hline \multirow[b]{3}{*}{ Metformin } & \multirow[b]{3}{*}{ 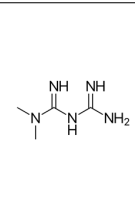 } & \multirow[b]{3}{*}{ Galega officinalis } & Male C57BL/6 mice & $0.1 \% w / w$ & $\uparrow$ Nrf2 expression & \multirow{2}{*}{ [72] } \\
\hline & & & $\mathrm{HepG}_{2}$ cells & $1.5 \mathrm{mM}$ & $\uparrow$ Nrf2-mediated antioxidant response & \\
\hline & & & C. elegans & $50 \mathrm{mM}$ & $\begin{array}{l}\uparrow \text { SKN-1 nuclear translocation in the intestine to } \\
\text { promote SKN-1-dependent transcription }\end{array}$ & [71] \\
\hline \multirow{3}{*}{ Curcumin } & \multirow{3}{*}{ ing } & \multirow{3}{*}{ Curcuma longa } & TRAMP C1 cells & $1,2.5 \mu \mathrm{M}$ & $\uparrow \mathrm{Nrf2}$ expression & [113] \\
\hline & & & C. elegans & $20 \mathrm{mM}$ & $\uparrow$ Nrf2-ARE binding & {$[82,83]$} \\
\hline & & & Uterine leiomyosarcoma cells & $50 \mu \mathrm{M}-48 \mathrm{~h}$ & Inhibitor of acetyltransferases & [85] \\
\hline \multirow{3}{*}{ Genistein } & & \multirow{3}{*}{ Soy products Vigna angularis } & $\begin{array}{l}\text { Rat model of transient global cerebral } \\
\text { ischemia }\end{array}$ & $1 \mathrm{mg} / \mathrm{kg}$ B.W. & $\uparrow$ Modification of Keap1/Nrf2 nuclear translocation & [90] \\
\hline & & & Ovarian cancer cells & $100 \mu \mathrm{M}-24 \mathrm{~h}$ & \multirow{2}{*}{ PI3K-Akt } & [93] \\
\hline & & & MCF7 cells & $100 \mu \mathrm{M}-72 \mathrm{~h}$ & & [92] \\
\hline \multirow{6}{*}{$\begin{array}{l}\text { Epigallocatechin } \\
\text { gallate (EGCG) }\end{array}$} & & \multirow{6}{*}{ Green tea Camilla sinensis } & B lymphoblasts & $30 \mu \mathrm{M}$ & $\uparrow \mathrm{PI} 3 \mathrm{~K} / \mathrm{Akt}$ & [113] \\
\hline & & & Macrophage foam cells & $40 \mu \mathrm{g} / \mathrm{mL}$ & Increased Nrf2-Keap1 dissociation & [108] \\
\hline & & & Human breast epithelial (MCF10A) cells & $100 \mu \mathrm{M}$ & $\begin{array}{l}\uparrow \text { Nrf2 nuclear translocation, Nrf2-ARE binding and } \\
\text { Nrf2 expression }\end{array}$ & [107] \\
\hline & & & NZB/W F1 lupus-prone mice & $120 \mathrm{mg} / \mathrm{kg}$ B.W. & $\uparrow$ Nrf2-mediated antioxidant response & [105] \\
\hline & & & Human umbilical vein endothelial cells & $50-400 \mu \mathrm{M}$ & $\uparrow \mathrm{Nrf2}$ and HO-1 expression & [106] \\
\hline & & & $\begin{array}{l}\text { Endothelial cells } \\
\end{array}$ & $10 \mu \mathrm{M}-4 \mathrm{~h}$ & AMPK & [112] \\
\hline
\end{tabular}




\section{Plant-Derived Natural Compounds Specifically Modulating Nrf2 and/or Proteasome Activity}

The activation of the UPS system by natural compounds, either directly or via its master regulator $\mathrm{Nrf2}$, has been reviewed in several cellular models, e.g., primary cultures of mammalian origin, as well as in yeast, worms, flies, rodents and humans and has been shown to result in extended cellular viability, lifespan extension and/or resistance to various types of stressors $[9,114]$; compounds with the potential to activate UPS or modulate Nrf2 activity are summarised in Table 2.

Sulforaphane is a natural product within the group of organosulfur compounds (glycosinolates) that can be isolated from cooked cruciferous vegetables and is present in a variety of oral supplements, containing its purified form or in broccoli sprout extract [115-118]. Sulforaphane has been characterised for its anti-cancer, anti-oxidant and anti-microbial properties most of which are attributed to its ability to activate the Keap1-Nrf2-ARE pathway [119]. The treatment of human HEK293 cells with 5-20 $\mu$ M of sulforaphane enhanced Nrf2 nuclear translocation by directly modifying Keap1 cysteines [38,119-122]. Acute or long-term administration of sulforaphane induces antioxidant and phase II drug metabolizing enzymes in several tissues [123-127]. Sulforaphane has also been found to exert chemopreventive effects against carcinogenesis in various types of carcinogen-induced and transgenic cancer models [91].

Reserpine, an indole alkaloid, is another compound from the group of glycosinolates, which is isolated from the dried root of Rauwolfia serpentine (Apocynaceae). Chronic administration ( $30 \mu \mathrm{M})$ of reserpine to $C$. elegans increased its lifespan by $31 \%$, provided stress tolerance and delayed age-related decline in the mobility of the worm [91]. These results are further supported by another study, which suggests that reserpine exerted cancer-preventive properties by reactivating Nrf2 and inducing the expression of cytoprotective genes [128]. Although the use of reserpine as an anti-ageing factor is rather promising, according to Drugs.com (Drugs Information Database) the clinical use of reserpine as anti-psychotic and anti-hypertensive drug (0.1-0.5 mg orally daily) revealed numerous side-effects, such as respiratory, psychiatric and cardiovascular complications.

Andrographolide, isolated from Andrographis paniculata (Acanthaceae) is a diterpene lactone compound that exhibits neuroprotective properties in both in vitro and in vivo experimental models of stroke [129]. Part of andrographolide's neuroprotective mechanism was attributed to the increase of the 2-heme oxygenase (HO-1) (Nrf2 transcriptional target) expression through p38-mitogen-activated protein kinase (MAPK) regulation, after the intraperitoneal injection of middle cerebral artery occlusion (MCAO)-insulted rats with $0.1 \mathrm{mg}$ of andrographolide per $\mathrm{kg}$ [130].

Phenolic compounds, are well known dietary supplements for several conditions but they should be carefully used after medical consultation due to side effects resulting from high dosing or potential pharmacological interactions with conventional therapies [131]. Besides the aforementioned curcumin, catechins and genistein other phenolic compounds were described to modulate proteasome activity and/or Nrf2 activity, as follows.

Cinnamic aldehyde (flavonoid) and pterostilbene (stilbenoid) are well-known Nrf2 activators used to treat diabetes [132]. Cinnamic aldehyde acts either directly on the Nrf2-Keap1 complex by modifying critical cysteine thiol residues of Keap1 or on upstream kinases such as Akt, ERK, PI3K, protein kinase C- (PKC) and c-Jun N-terminal kinase- (JNK) causing the release of Nrf2 from Keap1. On the other hand, the mechanism of pterostilbene is not well understood; however, it has been proposed that it increases the expression of target genes downstream of Nrf2 by promoting Nrf2 expression and nuclear translocation.

Oleuropein (phenylethanoid), the major constituent of Olea europea (Oleaceae) leaf extract, is a well-known natural compound with anti-tumour and anti-inflammatory properties due to its anti-oxidant potency and radical scavenging ability [133]. It was also found to suppress oxidative stress, reduce protein oxidation and increase all three proteasome activities in human embryonic fibroblasts at a concentration of $0.5 \mu \mathrm{g} / \mathrm{mL}$; moreover, it was found to delay cellular senescence by approximately 15\% [134]. Interestingly, in contrast to other proteasome activators with either relatively low potency or high molecular mass, oleuropein is a small molecule that activates the proteasome at low concentrations [135]. 
Osthole, a compound from the coumarin group isolated from the seeds of Cnidium monnieri (Apiaceae) presents a variety of health-beneficial properties such as neuroprotection, hepatoprotection, cardiovascular protection, prevention against cancer, inflammation and infections and modulation of the immune system [136]. In fact the administration of osthole (daily dose of $30 \mathrm{mg} / \mathrm{kg}$ body weight by intraperitoneal injection) improved an accelerated, early stage, focal segmental glomerulosclerosis mouse model by activating Nrf2 and subsequently inhibiting nuclear factor kappa-light-chain-enhancer of activated B cells- (NF-kB)-mediated cyclooxygenase 2- (Cox-2) expression and apoptosis [137]. In addition, osthole was shown to reduce inflammation induced by lipopolysaccharide in BV2 cells in a dose-dependent manner via among others the activation of the Nrf2 pathway [138]. Increased protein levels of Nrf2 and HO-1 along with the neuroprotective properties of this compound were revealed after the treatment of C57 BL/6J mice with transient global brain ischemia with $100 \mathrm{mg} / \mathrm{kg}$ of osthole [139].

Last but not least among the phenolic acids that have been suggested to act as Nrf2 activators [140]; rosmarinic acid (at $200 \mu \mathrm{M}$ ) extended lifespan (by $\sim 11 \%$ ) and enhanced thermotolerance of $C$. elegans via its antioxidant properties [141].

Finally it should be mentioned that although the compounds described above have been scientifically proven to act as Nrf2 or proteasome activators in several model organisms (Table 2) they have not been employed in anti-ageing oriented clinical trials yet. According to clinicaltrials.gov coordinated by the U.S. National Library of Medicine (NIH) most of them have been examined as therapies for age-related disorders, such as cancer, diabetes mellitus type 2 and cardiovascular and neurodegenerative diseases but not as factors that could potentially extend healthy ageing or delay the onset of age-related diseases. Several challenges have to be faced in order to extrapolate these studies from model organisms to humans due to the complex human physiology, the diversity of human ageing phenotypes, potential adverse effects and, most important, the need for well-defined, measurable, ageing or age-associated outcomes [142]. 
Table 2. Natural products modulating Nrf2 and/or ubiquitin-proteasome system (UPS) activity.

\begin{tabular}{|c|c|c|c|c|c|c|}
\hline Compound & Structure & Source & Model & Dose Used & Proposed Mechanism of Action & Reference \\
\hline \multirow{3}{*}{ Sulforaphane } & \multirow{3}{*}{ 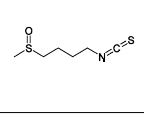 } & \multirow{3}{*}{$\begin{array}{l}\text { Cruciferous } \\
\text { vegetables }\end{array}$} & Human Keap1-transfected HEK293 cells & $5-20 \mu \mathrm{M}$ & Modification of Keap1 & \multirow{2}{*}{ [113] } \\
\hline & & & TRAMP C1 cells & $1,2.5 \mu \mathrm{M}$ & $\uparrow \mathrm{Nrf2}$ expression & \\
\hline & & & Mouse embryonic fibroblasts & $10 \mu \mathrm{M}$ & $\uparrow$ Nrf2 expression & [143] \\
\hline Reserpine & $x_{0}$ & Rauwolfia serpentine & Mouse skin epidermal JB6 P + cells & $2.5-10 \mu \mathrm{M}$ & $\uparrow$ Nrf2 expression & [128] \\
\hline Andrographolide & & $\begin{array}{l}\text { Andrographis } \\
\text { paniculata }\end{array}$ & $\begin{array}{l}\text { Middle cerebral artery occlusion } \\
\text { (MCAO)-insulted rats }\end{array}$ & $0.1 \mathrm{mg} / \mathrm{kg}$ B.W. & $\uparrow \mathrm{Nrf2}$ and HO-1 expression & [129] \\
\hline \multirow{4}{*}{ Cinnamic aldehyde } & & \multirow{4}{*}{ Сinnamomuт verum } & Endothelial cells & $100 \mu \mathrm{M}$ & $\uparrow$ Nrf2 and HO-1 expression & [113] \\
\hline & & & Human epithelial colon cells & $10 \uparrow$ & Nrf2-mediated antioxidant response & \multirow{3}{*}{ [132] } \\
\hline & & & HepG2 cells & $100 \mu \mathrm{M}$ & $\uparrow$ Nrf2 nuclear translocation & \\
\hline & & & STZ-induced diabetic mice $\left(\mathrm{Nrf}^{+/+}\right)$ & $20 \mathrm{mg} / \mathrm{kg}$ B.W. & $\uparrow$ Nrf2 expression & \\
\hline \multirow{3}{*}{ Pterostilbene } & \multirow{3}{*}{ 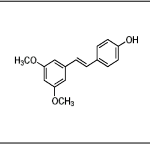 } & \multirow{3}{*}{$\begin{array}{l}\text { Grapes and } \\
\text { blueberries }\end{array}$} & Male BALB/c mice & $5 \mathrm{mg} / \mathrm{kg}$ B.W. & $\uparrow$ Nrf2 and HO-1 expression & [113] \\
\hline & & & $\begin{array}{l}\text { Tumor xenografts (nude mice) of } \\
\text { HEK293T cells }\end{array}$ & $100,200 \mathrm{mg} / \mathrm{kg}$ B.W. & $\uparrow \mathrm{Nrf2}$ expression & \multirow[t]{2}{*}{ [132] } \\
\hline & & & INS-1E cells & $2-16 \mu \mathrm{M}$ & $\uparrow$ Nrf2 activation and expression & \\
\hline \multirow[t]{2}{*}{ Oleuropein } & & \multirow{2}{*}{$\begin{array}{l}\text { Olea europa leaves } \\
\text { (green olives, olive } \\
\text { leaves, argan oil) }\end{array}$} & \multirow{2}{*}{ Human embryonic fibroblasts } & \multirow{2}{*}{$0.5 \mu \mathrm{g} / \mathrm{mL}$} & $\uparrow$ In vitro proteasome activities & \multirow[t]{2}{*}{ [134] } \\
\hline & & & & & $\uparrow$ Resistance to oxidative stress and cellular lifespan & \\
\hline \multirow{2}{*}{ Osthole } & & \multirow{2}{*}{ Cnidium monnerii } & Focal segmental glomerulosclerosis mice & $30 \mathrm{mg} / \mathrm{kg}$ B.W. & $\uparrow$ Nrf2-mediated antioxidant response & [137] \\
\hline & & & C57 BL/6J mice & $100 \mathrm{mg} / \mathrm{kg}$ B.W. & $\uparrow$ Nrf2 protein levels & [137] \\
\hline \multirow[t]{2}{*}{ Rosmarinic (carnosic) acid } & \multirow{2}{*}{ ros } & \multirow{2}{*}{$\begin{array}{l}\text { Rosmarinus officinalis } \\
\text { and Salvia officinalis }\end{array}$} & $\begin{array}{l}\text { Mouse model of isoproterenol } \\
\text { (ISO)-induced myocardial stress }\end{array}$ & $50,100 \mathrm{mg} / \mathrm{kg}$ B.W. & $\uparrow$ Nrf2 nuclear translocation & [140] \\
\hline & & & C. elegans & $200 \mu \mathrm{M}$ & $\uparrow$ Nrf2 mediated antioxidant response & [139] \\
\hline
\end{tabular}




\section{Natural Compounds That Act as Autophagy Inducers}

In the following section, we review the main compounds found to activate autophagy (Table 3) and consequently prolong lifespan in various models. The molecular targets (where known) for these compounds in mammalian cells are shown in Figure 3.

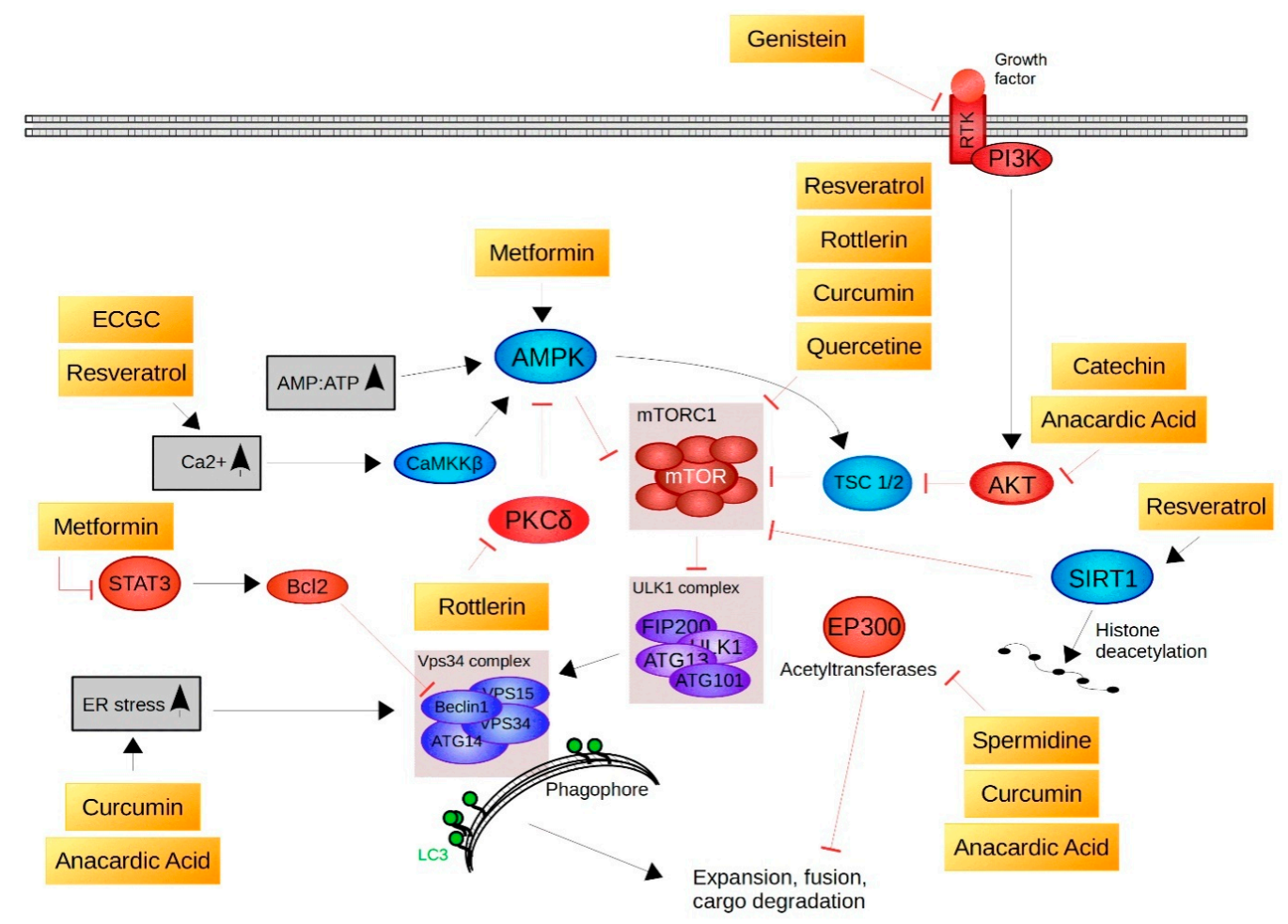

Figure 3. Natural compounds driving autophagy initiation. Plant-derived compounds (shown in yellow) induce autophagy by influencing cellular stressors (shown in grey); by activating positive regulators (shown in blue), or by repressing negative regulators (shown in red) of autophagy.

Spermidine ( $\mathrm{N}$-(3-aminopropyl) butane-1,4-diamine) is a natural polyamine that is synthesised by and present in many plants, animals and also humans [144]. Treatment with spermidine extends the life expectancy of Saccharomyces cerevisiae, Caenorhabditis elegans, Drosophila melanogaster, Mus musculus as well as the replicative potential of normal human cells and improves cardiac function in rodent models $[145,146]$. Autophagy activation was reported to be critical for spermidine-mediated increased longevity and for the cardioprotective effects in mice and humans [146,147]. Pietrocola et al. [60] recently suggested that incubation of human osteosarcoma U2OS cells with $100 \mu \mathrm{M}$ spermidine for $4 \mathrm{~h}$ activates the autophagy machinery by inhibiting acetyltransferases such as EP300. EP300 senses nutrient-dependent acetyl-CoA levels and inhibits important autophagy regulators including ATG5, ATG7, ATG12 and LC3 [60]. Regarding neuroprotection, it was suggested that $1 \mathrm{mM}$ spermidine $(1 \mathrm{~h})$ prevents staurosporine-induced neuronal injury in PC12 cells (rat pheochromocytoma cells) and rat cortical neurons by inhibiting caspase-3 and therefore blocking the cleavage of Beclin-1, which consequently restores autophagic flux [148].

Quercetin $\left(3,3^{\prime}, 4^{\prime}, 5,7\right.$-pentahydroxyflavone) is one of the most common dietary flavonoids found in vegetables and fruits, such as broccoli, onions, cherries, red grapes, apples and berries [149]. It is well known for its antioxidant activity and it was reported to induce apoptosis in numerous cancer cell lines [150]. Additionally, quercetin has been shown to augment resistance to oxidative stress and prolong lifespan in Saccharomyces cerevisiae and in Caenorhabditis elegans [151,152]. The anti-cellular senescence effect of $2 \mu \mathrm{g} / \mathrm{mL}$ quercetin ( 55 days of treatment) in human fibroblasts and its potential to rejuvenate senescent cells has been demonstrated [153]. Also, $24 \mathrm{~h}$ treatment with $50 \mu \mathrm{M}$ quercetin 
induced autophagy by de-phosphorylation and consequent inhibition of mTOR, as well as by downregulating anti-autophagic proteins like c-FLIP and v-FLIP in primary effusion lymphoma and in HeLa cells $[154,155]$.

Rottlerin [1-(6-[(3-acetyl-2,4,6-trihydroxy-5-methylphenyl)methyl]-5,7-dihydroxy-2,2-dimethyl-2H -1-benzopyran-8-yl) -3-phenyl-2-propen-1-one] also known as mallotoxin is a natural polyphenol that can be isolated from Mallotus philippinensis [156,157]. Rottlerin might be a potential agent for cancer treatment, e.g., breast cancer [158]. Yet, in spite of the cytotoxic activity of rottlerin against tumour cells, the primary, molecular mechanism of action remains unknown because this compound likely affects many different cellular processes [159]. Interestingly, various studies suggest that this compound is able to induce autophagy in different types of cancer cells [51,160]. Singh et al. [161] reported that $2 \mu \mathrm{M}$ rottlerin ( $24 \mathrm{~h}$ treatment) activated autophagy in pancreatic cancer stem cells by inhibiting mTOR signalling. In prostate cancer stem cells, it repressed mTOR accompanied by an increase in the expression of autophagy-related proteins including ATG5, ATG7, ATG12 and Beclin-1 [162]. Additionally, it is a selective PKC $\delta$-inhibitor, which in turn leads to NFKB-signalling repression and consequent activation of autophagy in breast, pancreatic and colon cancer cells [51].

Anacardic acid (6-pentadecylsalicylic acid) is synthesised by Anacardium occidentale (cashew tree), Ozora insignis, Gingko biloba and Amphipterygium adstringens and is a natural histone acetyltransferase inhibitor, that has antioxidant, anti-inflammatory, antimicrobial and anticancer properties [163,164]. Tan et al. [53] demonstrated that anacardic acid had the potential to induce autophagy in prostate cancer cells via the induction of ER-stress and repression of Akt signalling. Similarly, Seong et al. [165] demonstrated the stimulation of ER-stress related autophagy in lung adenocarcinoma cells A549 upon anacardic acid treatment $(3 \mu \mathrm{g} / \mathrm{mL} ; 24 \mathrm{~h})$. In U2OS cells, neuroglioma cells and also in murine embryonic fibroblasts administration of $50 \mu \mathrm{M}$ anacardic acid (4 h treatment) induced autophagy by inhibiting EP300 acetyltransferase, which directly represses autophagy proteins, including ATG5, ATG7, ATG12 and LC3 by acetylation [60]. 
Table 3. Plant extracts and natural compounds activating autophagy.

\begin{tabular}{|c|c|c|c|c|c|c|}
\hline Compound & Structure & Source & Model & Dose & Proposed Mechanism of Action & Reference \\
\hline Spermidine & ${ }_{\mathrm{H}_{2} \mathrm{~N}} \sim \mathrm{H}^{\mathrm{H}}$ & numerous & $\begin{array}{l}\text { U2OS, PC12 (rat pheochromocytoma } \\
\text { cells) }\end{array}$ & $\begin{array}{l}100 \mu \mathrm{M}-4 \mathrm{~h} \\
1 \mathrm{mM}-1 \mathrm{~h}\end{array}$ & $\begin{array}{l}\text { Inhibitor of acetyltransferases } \\
\text { Blocks Beclin-1 cleavage }\end{array}$ & {$[60,148]$} \\
\hline Quercetin & & numerous & Primary effusion lymphoma cells & $50 \mu \mathrm{M}-24 \mathrm{~h}$ & $\begin{array}{c}\text { mTOR inhibitor } \\
\text { Downregulation of anti-autophagic proteins }\end{array}$ & [154] \\
\hline Rottlerin & & Mallotus philippinensis & Pancreatic cancer stem cells & $2 \mu \mathrm{M}-24 \mathrm{~h}$ & $\begin{array}{l}\text { mTOR inhibitor } \\
\text { PKC } \delta \text { inhibitor }\end{array}$ & [162] \\
\hline Anacardic acid & & $\begin{array}{l}\text { Anacardium occidentale, Ozora } \\
\text { insignis, Gingko biloba, } \\
\text { Amphipterygium adstringens }\end{array}$ & U2OS, neuroglioma cells, MEF & $50 \mu \mathrm{M}-24 \mathrm{~h}$ & $\begin{array}{c}\text { ER-stress induction } \\
\text { Akt } \\
\text { Inhibitor of acetyltransferases }\end{array}$ & [60] \\
\hline Catechins & & Camilla sinensis & Endothelial cells & $10 \mu \mathrm{M}-4 \mathrm{~h}$ & AMPK & [110] \\
\hline
\end{tabular}




\section{Concluding Remarks}

Considering the rather modest estimation of plants containing $\sim 10^{5}$ bioactive compounds [166], the number of natural products (NPs) with demonstrated in vivo anti-ageing action remains extremely low. NPs represent an extraordinary inventory of highly diverse structural scaffolds that can be tested as potential chemopreventive agents. Nevertheless, most of the world's plant, marine, or microbial chemodiversity remains uninvestigated. Thus, carefully designed high-throughput, screening studies to identify compounds with activity against the aforementioned PN targets and downstream testing of selected hits in animal models or in human clinical trials will certainly reveal novel compounds that exert health-promoting properties.

As a note of caution, results obtained with model systems and model organisms cannot necessarily be extrapolated to humans. Another general concern relates to the possibility that some of the compounds described in this review, although showing clear beneficial effects on health-related parameters in model systems or model organisms, may display unexpected adverse effects upon routine application in humans. Whereas negative effects for any of the compounds covered by this review were not explicitly mentioned in the literature, except for quercetin, which causes emesis, nephrotoxicity, hypertension and reduction in serum potassium levels at a concentration of more than $945 \mathrm{mg} / \mathrm{m}^{2}$ intravenously injected in cancer patients [149], this does not mean that negative effects may not occur with other compounds as well; in this respect it should be noted that for any kind of compound, excessive doses may bear risks for human health, or, to quote Paracelsus: Sola dosis facit venenum. For these reasons, it will be very important in the future to include studies with humans for the most promising natural products.

Preferentially, edible fruits, spices, vegetables or other plant parts (e.g., roots) would be the first choice for these screenings. Furthermore, the identification of non-toxic doses is needed since in most (if not in all) cases, the use of pharmacological PN activators has revealed that the high-level expression of the target is not required for healthspan extension. Rather, mild chronic increases in the activity of proteostatic modules will likely be highly effective for the amelioration of toxicity induced by age-related proteome instability [167]. It is also encouraging that because of the high integrative nature of the PN, small readjustments of a single module (e.g., prevention of the age-dependent decline of proteasome and/or autophagy function) can lead to global beneficial effects indicating the intrinsic propensity of the PN to naturally rebalance as a whole.

In conclusion, tackling ageing and its consequences (increased disability and morbidity) is a much-needed task that, evidently, requires the combined effort of scientists from distinct disciplines including chemistry, pharmacy, biology and medicine. It is foreseen that the progress in understanding the genetic basis of ageing, along with the significant technological improvements in natural products isolation, characterization and tracking of bioactive constituents will lead to identification (e.g., from constituents of the Mediterranean-type diet) of novel natural compounds that will exert healthspanand/or lifespan-increasing properties and can be thus translated into significant health benefits for humans.

Author Contributions: All authors contributed in manuscript preparation. I.P.T. and P.J.-D. supervised the process.

Acknowledgments: We apologise to those authors whose work was not cited due to space limitations. I.P.T. and P.J.-D. acknowledge funding from the EU grant MEDIHEALTH (H2020-MSCA-RISE-2015, GA 691158).

Conflicts of Interest: The authors declare no conflict of interest. 


\section{Abbreviations}

\begin{tabular}{|c|c|}
\hline Akt & protein kinase B \\
\hline ALP & autophagy-lysosome pathway \\
\hline ARE & antioxidant response element \\
\hline ATG & autophagy-related gene \\
\hline b-TRCP & beta-transducin repeat-containing protein \\
\hline CaMKK $\beta$ & calmodulin-dependent protein kinase kinase $\beta$ \\
\hline $\mathrm{CP}$ & core particle \\
\hline $\mathrm{CR}$ & caloric restriction \\
\hline EGCG & epigallocatechin gallate \\
\hline eNOS & endothelial nitric oxide synthase \\
\hline EpRE & electrophile response element \\
\hline ER & endoplasmatic reticulum \\
\hline ERAD & ER associated protein degradation \\
\hline ERK1/2 & extracellular-signal-regulated kinase $1 / 2$ \\
\hline FoxO & forkhead box $\mathrm{O}$ \\
\hline GF & growth factor \\
\hline Gsk-3 & glycogen synthase kinase-3 \\
\hline Hsf1 & heat shock factor 1 \\
\hline Keap-1 & Kelch-like ECH- associated protein 1 \\
\hline Maf & v-Maf avian musculoaponeurotic fibrosarcoma oncogene homolog \\
\hline MnSOD & manganese superoxide dismutase \\
\hline mTOR & mechanistic target of rapamycin \\
\hline NP & natural product \\
\hline Nrf2 & nuclear factor erythroid 2-related factor 2 \\
\hline OMMAD & outer mitochondrial membrane-associated degradation \\
\hline OXPHOS & oxidative phosphorylation \\
\hline PGC- $1 \alpha$ & PPAR-gamma co-activator $1 \alpha$ \\
\hline PI3K & phosphoinositide 3-kinase \\
\hline PKC $\delta$ & protein kinase delta \\
\hline PN & proteostasis network \\
\hline ROS & reactive oxygen species \\
\hline $\mathrm{RP}$ & regulatory particle \\
\hline Stat3 & signal transducer and activator of transcription 3 \\
\hline TG2 & tissue transglutaminase 2 \\
\hline ULK & UNC-5 like autophagy activation kinase \\
\hline UPS & ubiquitin-proteasome system \\
\hline UPRER & unfolded protein response of the ER \\
\hline UPRmt & unfolded protein response of the mitochondria \\
\hline
\end{tabular}

\section{References}

1. Haigis, M.C.; Yankner, B.A. The Aging Stress Response. Mol. Cell 2010, 40, 333-344. [CrossRef] [PubMed]

2. Gumeni, S.; Trougakos, I.P. Cross Talk of Proteostasis and Mitostasis in Cellular Homeodynamics, Ageing, and Disease. Oxid. Med. Cell. Longev. 2016, 2016, 1-24. [CrossRef] [PubMed]

3. Reuter, S.; Gupta, S.C.; Chaturvedi, M.M.; Aggarwal, B.B. Oxidative stress, inflammation, and cancer: How are they linked? Free Radic. Biol. Med. 2010, 49, 1603-1616. [CrossRef] [PubMed]

4. Dröge, W. Free Radicals in the Physiological Control of Cell Function. Physiol. Rev. 2002, 82, 47-95. [CrossRef] [PubMed]

5. Valko, M.; Rhodes, C.J.; Moncol, J.; Izakovic, M.; Mazur, M. Free radicals, metals and antioxidants in oxidative stress-induced cancer. Chem. Biol. Interact. 2006, 160, 1-40. [CrossRef] [PubMed]

6. Klaips, C.L.; Jayaraj, G.G.; Hartl, F.U. Pathways of cellular proteostasis in aging and disease. J. Cell Biol. 2018, 217, 51-63. [CrossRef] [PubMed] 
7. Morimoto, R.I. Proteotoxic stress and inducible chaperone networks in neurodegenerative disease and aging. Genes Dev. 2008, 22, 1427-1438. [CrossRef] [PubMed]

8. Trougakos, I.P.; Sesti, F.; Tsakiri, E.; Gorgoulis, V.G. Non-enzymatic post-translational protein modifications and proteostasis network deregulation in carcinogenesis. J. Proteomics 2013, 92, 274-298. [CrossRef] [PubMed]

9. Tsakiri, E.N.; Trougakos, I.P. The Amazing Ubiquitin-Proteasome System: Structural Components and Implication in Aging. In International review of cell and molecular biology; 2015; Volume 314, pp. 171-237.

10. Sala, A.J.; Bott, L.C.; Morimoto, R.I. Shaping proteostasis at the cellular, tissue, and organismal level. J. Cell Biol. 2017, 216, 1231-1241. [CrossRef] [PubMed]

11. Rattan, S.I.S. Biogerontology: From here to where? The Lord Cohen Medal Lecture-2011. Biogerontology 2012, 13, 83-91. [CrossRef] [PubMed]

12. Kirkwood, T.B.L. Evolution of ageing. Mech. Ageing Dev. 2002, 123, 737-745. [CrossRef]

13. Campisi, J. Senescent Cells, Tumor Suppression, and Organismal Aging: Good Citizens, Bad Neighbors. Cell 2005, 120, 513-522. [CrossRef] [PubMed]

14. Niccoli, T.; Partridge, L. Ageing as a Risk Factor for Disease. Curr. Biol. 2012, 22, R741-R752. [CrossRef] [PubMed]

15. Argyropoulou, A.; Aligiannis, N.; Trougakos, I.P.; Skaltsounis, A.-L. Natural compounds with anti-ageing activity. Nat. Prod. Rep. 2013, 30, 1412. [CrossRef] [PubMed]

16. Balchin, D.; Hayer-Hartl, M.; Hartl, F.U. In vivo aspects of protein folding and quality control. Science 2016, 353, aac4354. [CrossRef] [PubMed]

17. Gidalevitz, T.; Ben-Zvi, A.; Ho, K.H.; Brignull, H.R.; Morimoto, R.I. Progressive disruption of cellular protein folding in models of polyglutamine diseases. Science 2006, 311, 1471-1474. [CrossRef] [PubMed]

18. Niforou, K.; Cheimonidou, C.; Trougakos, I.P. Molecular chaperones and proteostasis regulation during redox imbalance. Redox Biol. 2014, 2, 323-332. [CrossRef] [PubMed]

19. Balch, W.E.; Morimoto, R.I.; Dillin, A.; Kelly, J.W. Adapting proteostasis for disease intervention. Science 2008, 319, 916-919. [CrossRef] [PubMed]

20. Powers, E.T.; Morimoto, R.I.; Dillin, A.; Kelly, J.W.; Balch, W.E. Biological and Chemical Approaches to Diseases of Proteostasis Deficiency. Annu. Rev. Biochem. 2009, 78, 959-991. [CrossRef] [PubMed]

21. Gumeni, S.; Evangelakou, Z.; Gorgoulis, V.; Trougakos, I. Proteome Stability as a Key Factor of Genome Integrity. Int. J. Mol. Sci. 2017, 18, 2036. [CrossRef] [PubMed]

22. Calderwood, S.K.; Murshid, A.; Prince, T. The shock of aging: Molecular chaperones and the heat shock response in longevity and aging-A mini-review. Gerontology 2009, 55, 550-558. [CrossRef] [PubMed]

23. van der Horst, A.; Burgering, B.M.T. Stressing the role of FoxO proteins in lifespan and disease. Nat. Rev. Mol. Cell Biol. 2007, 8, 440-450. [CrossRef] [PubMed]

24. Sykiotis, G.P.; Bohmann, D. Stress-Activated Cap'n'collar Transcription Factors in Aging and Human Disease. Sci. Signal. 2010, 3, re3. [CrossRef] [PubMed]

25. Morimoto, R.I.; Driessen, A.J.M.; Hegde, R.S.; Langer, T. The life of proteins: The good, the mostly good and the ugly. Nat. Struct. Mol. Biol. 2011, 18, 1-4. [CrossRef] [PubMed]

26. 2Morimoto, R.I.; Cuervo, A.M. Proteostasis and the Aging Proteome in Health and Disease. J. Gerontol. A Biol. Sci. Med. Sci. 2014, 69, S33-S38. [CrossRef] [PubMed]

27. López-Otín, C.; Blasco, M.A.; Partridge, L.; Serrano, M.; Kroemer, G. The Hallmarks of Aging. Cell 2013, 153, 1194-1217. [CrossRef] [PubMed]

28. Vilchez, D.; Saez, I.; Dillin, A. The role of protein clearance mechanisms in organismal ageing and age-related diseases. Nat. Commun. 2014, 5, 5659. [CrossRef] [PubMed]

29. Jung, T.; Höhn, A.; Grune, T. The proteasome and the degradation of oxidized proteins: Part III-Redox regulation of the proteasomal system. Redox Biol. 2014, 2, 388-394. [CrossRef] [PubMed]

30. Saeki, Y.; Tanaka, K. Assembly and Function of the Proteasome. Methods Mol. Biol. 2012, 832, 315-337.

31. Finley, D.; Chen, X.; Walters, K.J. Gates, Channels, and Switches: Elements of the Proteasome Machine. Trends Biochem. Sci. 2016, 41, 77-93. [CrossRef] [PubMed]

32. Vembar, S.S.; Brodsky, J.L. One step at a time: Endoplasmic reticulum-associated degradation. Nat. Rev. Mol. Cell Biol. 2008, 9, 944-957. [CrossRef] [PubMed]

33. Neutzner, A.; Youle, R.J.; Karbowski, M. Outer mitochondrial membrane protein degradation by the proteasome. Novartis Found. Symp. 2007, 287, 4-20. [PubMed] 
34. Nedić, O.; Rattan, S.I.S.; Grune, T.; Trougakos, I.P. Molecular effects of advanced glycation end products on cell signalling pathways, ageing and pathophysiology. Free Radic. Res. 2013, 47, 28-38. [CrossRef] [PubMed]

35. Labbadia, J.; Morimoto, R.I. The Biology of Proteostasis in Aging and Disease. Annu. Rev. Biochem. 2015, 84, 435-464. [CrossRef] [PubMed]

36. Sklirou, A.; Papanagnou, E.-D.; Fokialakis, N.; Trougakos, I.P. Cancer chemoprevention via activation of proteostatic modules. Cancer Lett. 2018, 413, 110-121. [CrossRef] [PubMed]

37. Rada, P.; Rojo, A.I.; Chowdhry, S.; McMahon, M.; Hayes, J.D.; Cuadrado, A. SCF/\{beta\}-TrCP promotes glycogen synthase kinase 3-dependent degradation of the Nrf2 transcription factor in a Keap1-independent manner. Mol. Cell. Biol. 2011, 31, 1121-1133. [CrossRef] [PubMed]

38. Zhang, D.D.; Hannink, M. Distinct cysteine residues in Keap1 are required for Keap1-dependent ubiquitination of Nrf2 and for stabilization of Nrf2 by chemopreventive agents and oxidative stress. Mol. Cell. Biol. 2003, 23, 8137-8151. [CrossRef] [PubMed]

39. McMahon, M.; Itoh, K.; Yamamoto, M.; Hayes, J.D. Keap1-dependent Proteasomal Degradation of Transcription Factor Nrf2 Contributes to the Negative Regulation of Antioxidant Response Element-driven Gene Expression. J. Biol. Chem. 2003, 278, 21592-21600. [CrossRef] [PubMed]

40. Taguchi, K.; Motohashi, H.; Yamamoto, M. Molecular mechanisms of the Keap1-Nrf2 pathway in stress response and cancer evolution. Genes to Cells 2011, 16, 123-140. [CrossRef] [PubMed]

41. Kensler, T.W.; Wakabayashi, N. Nrf2: Friend or foe for chemoprevention? Carcinogenesis 2010, 31, 90-99. [CrossRef] [PubMed]

42. Li, X.; Matilainen, O.; Jin, C.; Glover-Cutter, K.M.; Holmberg, C.I.; Blackwell, T.K. Specific SKN-1/Nrf Stress Responses to Perturbations in Translation Elongation and Proteasome Activity. PLoS Genet. 2011, 7, e1002119. [CrossRef] [PubMed]

43. Tsakiri, E.N.; Sykiotis, G.P.; Papassideri, I.S.; Terpos, E.; Dimopoulos, M.A.; Gorgoulis, V.G.; Bohmann, D.; Trougakos, I.P. Proteasome dysfunction in Drosophila signals to an Nrf2-dependent regulatory circuit aiming to restore proteostasis and prevent premature aging. Aging Cell 2013, 12, 802-813. [CrossRef] [PubMed]

44. Tsakiri, E.N.; Iliaki, K.K.; Höhn, A.; Grimm, S.; Papassideri, I.S.; Grune, T.; Trougakos, I.P. Diet-derived advanced glycation end products or lipofuscin disrupts proteostasis and reduces life span in Drosophila melanogaster. Free Radic. Biol. Med. 2013, 65, 1155-1163. [CrossRef] [PubMed]

45. Tsakiri, E.N.; Sykiotis, G.P.; Papassideri, I.S.; Gorgoulis, V.G.; Bohmann, D.; Trougakos, I.P. Differential regulation of proteasome functionality in reproductive $v s$. somatic tissues of Drosophila during aging or oxidative stress. FASEB J. 2013, 27, 2407-2420. [CrossRef] [PubMed]

46. Yin, Z.; Pascual, C.; Klionsky, D.J. Autophagy: Machinery and regulation. Microb. Cell 2016, 3. [CrossRef] [PubMed]

47. Bento, C.F.; Renna, M.; Ghislat, G.; Puri, C.; Ashkenazi, A.; Vicinanza, M.; Menzies, F.M.; Rubinsztein, D.C. Mammalian Autophagy: How Does It Work? Annu. Rev. Biochem. 2016, 85, 685-713. [CrossRef] [PubMed]

48. Kim, Y.C.; Guan, K.-L. mTOR: A pharmacologic target for autophagy regulation. J. Clin. Investig. 2015, 125, 25-32. [CrossRef] [PubMed]

49. Galluzzi, L.; Baehrecke, E.H.; Ballabio, A.; Boya, P.; Bravo-San Pedro, J.M.; Cecconi, F.; Choi, A.M.; Chu, C.T.; Codogno, P.; Colombo, M.I.; et al. Molecular definitions of autophagy and related processes. EMBO J. 2017, 36, 1811-1836. [CrossRef] [PubMed]

50. Madeo, F.; Zimmermann, A.; Maiuri, M.C.; Kroemer, G. Essential role for autophagy in life span extension. J. Clin. Investig. 2015, 125, 85-93. [CrossRef] [PubMed]

51. Hasima, N.; Ozpolat, B. Regulation of autophagy by polyphenolic compounds as a potential therapeutic strategy for cancer. Cell Death Dis. 2014, 5, e1509. [CrossRef] [PubMed]

52. Vingtdeux, V.; Giliberto, L.; Zhao, H.; Chandakkar, P.; Wu, Q.; Simon, J.E.; Janle, E.M.; Lobo, J.; Ferruzzi, M.G.; Davies, P.; Marambaud, P. AMP-activated Protein Kinase Signaling Activation by Resveratrol Modulates Amyloid- $\beta$ Peptide Metabolism. J. Biol. Chem. 2010, 285, 9100-9113. [CrossRef] [PubMed]

53. Tan, J.; Jiang, X.; Yin, G.; He, L.; Liu, J.; Long, Z.; Jiang, Z.; Yao, K. Anacardic acid induces cell apoptosis of prostatic cancer through autophagy by ER stress/DAPK3/Akt signaling pathway. Oncol. Rep. 2017, 38, 1373-1382. [CrossRef] [PubMed] 
54. Qu, W.; Xiao, J.; Zhang, H.; Chen, Q.; Wang, Z.; Shi, H.; Gong, L.; Chen, J.; Liu, Y.; Cao, R.; et al. B19, a Novel Monocarbonyl Analogue of Curcumin, Induces Human Ovarian Cancer Cell Apoptosis via Activation of Endoplasmic Reticulum Stress and the Autophagy Signaling Pathway. Int. J. Biol. Sci. 2013, 9, 766-777. [CrossRef] [PubMed]

55. Feng, Y.; Ke, C.; Tang, Q.; Dong, H.; Zheng, X.; Lin, W.; Ke, J.; Huang, J.; Yeung, S.-C.; Zhang, H. Metformin promotes autophagy and apoptosis in esophageal squamous cell carcinoma by downregulating Stat3 signaling. Cell Death Dis. 2014, 5, e1088. [CrossRef] [PubMed]

56. Akar, U.; Chaves-Reyez, A.; Barria, M.; Tari, A.; Sanguino, A.; Kondo, Y.; Kondo, S.; Arun, B.; Lopez-Berestein, G.; Ozpolat, B. Silencing of Bcl-2 expression by small interfering RNA induces autophagic cell death in MCF-7 breast cancer cells. Autophagy 2008, 4, 669-679. [CrossRef] [PubMed]

57. Bhullar, K.S.; Hubbard, B.P. Lifespan and healthspan extension by resveratrol. Biochim. Biophys. Acta 2015, 1852, 1209-1218. [CrossRef] [PubMed]

58. Berman, A.Y.; Motechin, R.A.; Wiesenfeld, M.Y.; Holz, M.K. The therapeutic potential of resveratrol: A review of clinical trials. NPJ Precis. Oncol. 2017, 1, 35. [CrossRef] [PubMed]

59. Morselli, E.; Maiuri, M.C.; Markaki, M.; Megalou, E.; Pasparaki, A.; Palikaras, K.; Criollo, A.; Galluzzi, L.; Malik, S.A.; Vitale, I.; et al. The life span-prolonging effect of Sirtuin-1 is mediated by autophagy. Autophagy 2010, 6, 186-188. [CrossRef] [PubMed]

60. Pietrocola, F.; Lachkar, S.; Enot, D.P.; Niso-Santano, M.; Bravo-San Pedro, J.M.; Sica, V.; Izzo, V.; Maiuri, M.C.; Madeo, F.; Mariño, G.; et al. Spermidine induces autophagy by inhibiting the acetyltransferase EP300. Cell Death Differ. 2015, 22, 509-516. [CrossRef] [PubMed]

61. Dalby, K.N.; Tekedereli, I.; Lopez-Berestein, G.; Ozpolat, B. Targeting the prodeath and prosurvival functions of autophagy as novel therapeutic strategies in cancer. Autophagy 2010, 6, 322-329. [CrossRef] [PubMed]

62. Kroemer, G. Autophagy: A druggable process that is deregulated in aging and human disease. J. Clin. Investig. 2015, 125, 1-4. [CrossRef] [PubMed]

63. Morselli, E.; Mariño, G.; Bennetzen, M.V; Eisenberg, T.; Megalou, E.; Schroeder, S.; Cabrera, S.; Bénit, P.; Rustin, P.; Criollo, A.; et al. Spermidine and resveratrol induce autophagy by distinct pathways converging on the acetylproteome. J. Cell Biol. 2011, 192, 615-629. [CrossRef] [PubMed]

64. Baur, J.A.; Sinclair, D.A. Therapeutic potential of resveratrol: The in vivo evidence. Nat. Rev. Drug Discov. 2006, 5, 493-506. [CrossRef] [PubMed]

65. Kou, X.; Chen, N. Resveratrol as a Natural Autophagy Regulator for Prevention and Treatment of Alzheimer's Disease. Nutrients 2017, 9, 927. [CrossRef]

66. Diaz-Gerevini, G.T.; Repossi, G.; Dain, A.; Tarres, M.C.; Das, U.N.; Eynard, A.R. Beneficial action of resveratrol: How and why? Nutrition 2016, 32, 174-178. [CrossRef] [PubMed]

67. Wu, Y.; Li, X.; Zhu, J.X.; Xie, W.; Le, W.; Fan, Z.; Jankovic, J.; Pan, T. Resveratrol-Activated AMPK/SIRT1/Autophagy in Cellular Models of Parkinson's Disease. Neurosignals 2011, 19, 163-174. [CrossRef] [PubMed]

68. Park, D.; Jeong, H.; Lee, M.N.; Koh, A.; Kwon, O.; Yang, Y.R.; Noh, J.; Suh, P.-G.; Park, H.; Ryu, S.H. Resveratrol induces autophagy by directly inhibiting mTOR through ATP competition. Sci. Rep. 2016, 6, 21772. [CrossRef] [PubMed]

69. Tamaki, N.; Cristina Orihuela-Campos, R.; Inagaki, Y.; Fukui, M.; Nagata, T.; Ito, H.-O. Resveratrol improves oxidative stress and prevents the progression of periodontitis via the activation of the Sirt1/AMPK and the Nrf2/antioxidant defense pathways in a rat periodontitis model. Free Radic. Biol. Med. 2014, 75, 222-229. [CrossRef] [PubMed]

70. Sadi, G.; Bozan, D.; Yildiz, H.B. Redox regulation of antioxidant enzymes: Post-translational modulation of catalase and glutathione peroxidase activity by resveratrol in diabetic rat liver. Mol. Cell. Biochem. 2014, 393, 111-122. [CrossRef] [PubMed]

71. Onken, B.; Driscoll, M. Metformin Induces a Dietary Restriction-Like State and the Oxidative Stress Response to Extend C. elegans Healthspan via AMPK, LKB1, and SKN-1. PLoS ONE 2010, 5, e8758. [CrossRef] [PubMed]

72. Martin-Montalvo, A.; Mercken, E.M.; Mitchell, S.J.; Palacios, H.H.; Mote, P.L.; Scheibye-Knudsen, M.; Gomes, A.P.; Ward, T.M.; Minor, R.K.; Blouin, M.-J.; et al. Metformin improves healthspan and lifespan in mice. Nat. Commun. 2013, 4, 2192. [CrossRef] [PubMed] 
73. Podhorecka, M.; Ibanez, B.; Dmoszyńska, A. Metformin-Its potential anti-cancer and anti-aging effects. Postep. Hig Med Dosw 2017, 71, 170-175. [CrossRef]

74. Wang, G.-Y.; Bi, Y.-G.; Liu, X.-D.; Zhao, Y.; Han, J.-F.; Wei, M.; Zhang, Q.-Y. Autophagy was involved in the protective effect of metformin on hyperglycemia-induced cardiomyocyte apoptosis and Connexin 43 downregulation in H9c2 cells. Int. J. Med. Sci. 2017, 14, 698-704. [CrossRef] [PubMed]

75. He, C.; Zhu, H.; Li, H.; Zou, M.-H.; Xie, Z. Dissociation of Bcl-2-Beclin1 complex by activated AMPK enhances cardiac autophagy and protects against cardiomyocyte apoptosis in diabetes. Diabetes 2013, 62, 1270-1281. [CrossRef] [PubMed]

76. Tomic, T.; Botton, T.; Cerezo, M.; Robert, G.; Luciano, F.; Puissant, A.; Gounon, P.; Allegra, M.; Bertolotto, C.; Bereder, J.-M.; et al. Metformin inhibits melanoma development through autophagy and apoptosis mechanisms. Cell Death Dis. 2011, 2, e199. [CrossRef] [PubMed]

77. Guo, S.; Long, M.; Li, X.; Zhu, S.; Zhang, M.; Yang, Z. Curcumin activates autophagy and attenuates oxidative damage in EA.hy926 cells via the Akt/mTOR pathway. Mol. Med. Rep. 2016, 13, 2187-2193. [CrossRef] [PubMed]

78. Shailaja, M.; Damodara Gowda, K.M.; Vishakh, K.; Suchetha Kumari, N. Anti-aging Role of Curcumin by Modulating the Inflammatory Markers in Albino Wistar Rats. J. Natl. Med. Assoc. 2017, 109, 9-13. [CrossRef] [PubMed]

79. Shen, L.-R.; Parnell, L.D.; Ordovas, J.M.; Lai, C.-Q. Curcumin and aging. BioFactors 2013, 39, $133-140$. [CrossRef] [PubMed]

80. Lee, K.-S.; Lee, B.-S.; Semnani, S.; Avanesian, A.; Um, C.-Y.; Jeon, H.-J.; Seong, K.-M.; Yu, K.; Min, K.-J.; Jafari, M. Curcumin Extends Life Span, Improves Health Span, and Modulates the Expression of Age-Associated Aging Genes in Drosophila melanogaster. Rejuvenation Res. 2010, 13, 561-570. [CrossRef] [PubMed]

81. Shen, L.-R.; Xiao, F.; Yuan, P.; Chen, Y.; Gao, Q.-K.; Parnell, L.D.; Meydani, M.; Ordovas, J.M.; Li, D.; Lai, C.-Q. Curcumin-supplemented diets increase superoxide dismutase activity and mean lifespan in Drosophila. Age (Omaha) 2013, 35, 1133-1142. [CrossRef] [PubMed]

82. Scapagnini, G.; Sonya, V.; Nader, A.G.; Calogero, C.; Zella, D.; Fabio, G.; Calogero, C.; Zella, D.; Fabio, G. Modulation of Nrf2/ARE Pathway by Food Polyphenols: A Nutritional Neuroprotective Strategy for Cognitive and Neurodegenerative Disorders. Mol. Neurobiol. 2011, 44, 192-201. [CrossRef] [PubMed]

83. Liao, V.H.-C.; Yu, C.-W.; Chu, Y.-J.; Li, W.-H.; Hsieh, Y.-C.; Wang, T.-T. Curcumin-mediated lifespan extension in Caenorhabditis elegans. Mech. Ageing Dev. 2011, 132, 480-487. [CrossRef] [PubMed]

84. Basile, V.; Belluti, S.; Ferrari, E.; Gozzoli, C.; Ganassi, S.; Quaglino, D.; Saladini, M.; Imbriano, C. bis-Dehydroxy-Curcumin Triggers Mitochondrial-Associated Cell Death in Human Colon Cancer Cells through ER-Stress Induced Autophagy. PLoS ONE 2013, 8, e53664. [CrossRef] [PubMed]

85. Li, B.; Takeda, T.; Tsuiji, K.; Wong, T.F.; Tadakawa, M.; Kondo, A.; Nagase, S.; Yaegashi, N. Curcumin Induces Cross-Regulation Between Autophagy and Apoptosis in Uterine Leiomyosarcoma Cells. Int. J. Gynecol. Cancer 2013, 23, 803-808. [CrossRef] [PubMed]

86. Xiao, K.; Jiang, J.; Guan, C.; Dong, C.; Wang, G.; Bai, L.; Sun, J.; Hu, C.; Bai, C. Curcumin Induces Autophagy via Activating the AMPK Signaling Pathway in Lung Adenocarcinoma Cells. J. Pharmacol. Sci. 2013, 123, 102-109. [CrossRef] [PubMed]

87. Fu, H.; Wang, C.; Yang, D.; Zhang, X.; Wei, Z.; Zhu, Z.; Xu, J.; Hu, Z.; Zhang, Y.; Wang, W.; et al. Curcumin regulates proliferation, autophagy and apoptosis in gastric cancer cells by affecting PI3K and P53 signaling. J. Cell. Physiol. 2017. [CrossRef] [PubMed]

88. Irrera, N.; Pizzino, G.; D’Anna, R.; Vaccaro, M.; Arcoraci, V.; Squadrito, F.; Altavilla, D.; Bitto, A. Dietary Management of Skin Health: The Role of Genistein. Nutrients 2017, 9, 622. [CrossRef] [PubMed]

89. Lee, E.B.; Ahn, D.; Kim, B.J.; Lee, S.Y.; Seo, H.W.; Cha, Y.-S.; Jeon, H.; Eun, J.S.; Cha, D.S.; Kim, D.K. Genistein from Vigna angularis Extends Lifespan in Caenorhabditis elegans. Biomol. Ther. (Seoul) 2015, 23, 77-83. [CrossRef] [PubMed]

90. Wang, R.; Tu, J.; Zhang, Q.; Zhang, X.; Zhu, Y.; Ma, W.; Cheng, C.; Brann, D.W.; Yang, F. Genistein attenuates ischemic oxidative damage and behavioral deficits via eNOS/Nrf2/HO-1 signaling. Hippocampus 2013, 23, 634-647. [CrossRef] [PubMed]

91. Huang, Y.; Li, W.; Su, Z.; Kong, A.-N.T. The complexity of the Nrf2 pathway: Beyond the antioxidant response. J. Nutr. Biochem. 2015, 26, 1401-1413. [CrossRef] [PubMed] 
92. Prietsch, R.F.; Monte, L.G.; da Silva, F.A.; Beira, F.T.; Del Pino, F.A.B.; Campos, V.F.; Collares, T.; Pinto, L.S.; Spanevello, R.M.; et al. Genistein induces apoptosis and autophagy in human breast MCF-7 cells by modulating the expression of proapoptotic factors and oxidative stress enzymes. Mol. Cell. Biochem. 2014, 390, 235-242. [CrossRef] [PubMed]

93. Gossner, G.; Choi, M.; Tan, L.; FOGOROS, S.; Griffith, K.; Kuenker, M.; Liu, J. Genistein-induced apoptosis and autophagocytosis in ovarian cancer cells. Gynecol. Oncol. 2007, 105, 23-30. [CrossRef] [PubMed]

94. Chacko, S.M.; Thambi, P.T.; Kuttan, R.; Nishigaki, I. Beneficial effects of green tea: A literature review. Chin. Med. 2010, 5, 13. [CrossRef] [PubMed]

95. Yang, Y.; Qin, Y.J.; Yip, Y.W.Y.; Chan, K.P.; Chu, K.O.; Chu, W.K.; Ng, T.K.; Pang, C.P.; Chan, S.O. Green tea catechins are potent anti-oxidants that ameliorate sodium iodate-induced retinal degeneration in rats. Sci. Rep. 2016, 6, 29546. [CrossRef] [PubMed]

96. Hong, Y.-H.; Jung, E.Y.; Shin, K.-S.; Yu, K.-W.; Chang, U.J.; Suh, H.J. Tannase-converted green tea catechins and their anti-wrinkle activity in humans. J. Cosmet. Dermatol. 2013, 12, 137-143. [CrossRef] [PubMed]

97. Pallauf, K.; Duckstein, N.; Rimbach, G. A literature review of flavonoids and lifespan in model organisms. Proc. Nutr. Soc. 2017, 76, 145-162. [CrossRef] [PubMed]

98. Kitani, K.; Osawa, T.; Yokozawa, T. The effects of tetrahydrocurcumin and green tea polyphenol on the survival of male C57BL/6 mice. Biogerontology 2007, 8, 567-573. [CrossRef] [PubMed]

99. Surco-Laos, F.; Dueñas, M.; González-Manzano, S.; Cabello, J.; Santos-Buelga, C.; González-Paramás, A.M. Influence of catechins and their methylated metabolites on lifespan and resistance to oxidative and thermal stress of Caenorhabditis elegans and epicatechin uptake. Food Res. Int. 2012, 46, 514-521. [CrossRef]

100. Sunagawa, T.; Shimizu, T.; Kanda, T.; Tagashira, M.; Sami, M.; Shirasawa, T. Procyanidins from Apples (Malus pumila Mill.) Extend the Lifespan of Caenorhabditis elegans. Planta Med. 2011, 77, 122-127. [CrossRef] [PubMed]

101. Saul, N.; Pietsch, K.; Menzel, R.; Stürzenbaum, S.R.; Steinberg, C.E.W. Catechin induced longevity in C. elegans: From key regulator genes to disposable soma. Mech. Ageing Dev. 2009, 130, 477-486. [CrossRef] [PubMed]

102. Abbas, S.; Wink, M. Epigallocatechin Gallate from Green Tea (Camellia sinensis) Increases Lifespan and Stress Resistance in Caenorhabditis elegans. Planta Med. 2009, 75, 216-221. [CrossRef] [PubMed]

103. Abbas, S.; Wink, M. Epigallocatechin gallate inhibits beta amyloid oligomerization in Caenorhabditis elegans and affects the daf-2/insulin-like signaling pathway. Phytomedicine 2010, 17, 902-909. [CrossRef] [PubMed]

104. Zhang, H.; Kong, X.; Kang, J.; Su, J.; Li, Y.; Zhong, J.; Sun, L. Oxidative Stress Induces Parallel Autophagy and Mitochondria Dysfunction in Human Glioma U251 Cells. Toxicol. Sci. 2009, 110, 376-388. [CrossRef] [PubMed]

105. Tsai, P.-Y.; Ka, S.-M.; Chang, J.-M.; Chen, H.-C.; Shui, H.-A.; Li, C.-Y.; Hua, K.-F.; Chang, W.-L.; Huang, J.-J.; Yang, S.-S.; et al. Epigallocatechin-3-gallate prevents lupus nephritis development in mice via enhancing the Nrf2 antioxidant pathway and inhibiting NLRP3 inflammasome activation. Free Radic. Biol. Med. 2011, 51, 744-754. [CrossRef] [PubMed]

106. Yang, G.-Z.; Wang, Z.-J.; Bai, F.; Qin, X.-J.; Cao, J.; Lv, J.-Y.; Zhang, M.-S. Epigallocatechin-3-Gallate Protects HUVECs from PM2.5-Induced Oxidative Stress Injury by Activating Critical Antioxidant Pathways. Molecules 2015, 20, 6626-6639. [CrossRef] [PubMed]

107. Na, H.-K.; Kim, E.-H.; Jung, J.-H.; Lee, H.-H.; Hyun, J.-W.; Surh, Y.-J. (-)-Epigallocatechin gallate induces Nrf2-mediated antioxidant enzyme expression via activation of PI3K and ERK in human mammary epithelial cells. Arch. Biochem. Biophys. 2008, 476, 171-177. [CrossRef] [PubMed]

108. Jiang, Z.-S.; Tang, C.-K.; Mo, Z.-C.; Yin, K.; Zhao, G.-J.; Lv, Y.-C.; Ouyang, X.-P.; Fu, Y.; Tang, C.-K. Epigallocatechin-3-gallate prevents TNF- $\alpha$-induced NF- $\mathrm{kB}$ activation thereby upregulating ABCA1 via the Nrf2/Keap1 pathway in macrophage foam cells. Int. J. Mol. Med. 2012, 29, 946-956. [CrossRef] [PubMed]

109. Kanzaki, H.; Shinohara, F.; Itohiya-Kasuya, K.; Ishikawa, M.; Nakamura, Y. Nrf2 Activation Attenuates Both Orthodontic Tooth Movement and Relapse. J. Dent. Res. 2015, 94, 787-794. [CrossRef] [PubMed]

110. Kim, H.-S.; Quon, M.J.; Kim, J. New insights into the mechanisms of polyphenols beyond antioxidant properties; lessons from the green tea polyphenol, epigallocatechin 3-gallate. Redox Biol. 2014, 2, 187-195. [CrossRef] [PubMed] 
111. Chen, C.-M.; Wu, C.-T.; Yang, T.-H.; Chang, Y.-A.; Sheu, M.-L.; Liu, S.H. Green Tea Catechin Prevents Hypoxia/Reperfusion-Evoked Oxidative Stress-Regulated Autophagy-Activated Apoptosis and Cell Death in Microglial Cells. J. Agric. Food Chem. 2016, 64, 4078-4085. [CrossRef] [PubMed]

112. Kim, H.-S.; Montana, V.; Jang, H.-J.; Parpura, V.; Kim, J. Epigallocatechin Gallate (EGCG) Stimulates Autophagy in Vascular Endothelial Cells. J. Biol. Chem. 2013, 288, 22693-22705. [CrossRef] [PubMed]

113. Qin, S.; Hou, D.-X. Multiple regulations of Keap1/Nrf2 system by dietary phytochemicals. Mol. Nutr. Food Res. 2016, 60, 1731-1755. [CrossRef] [PubMed]

114. Chondrogianni, N.; Gonos, E.S. Proteasome activation as a novel antiaging strategy. IUBMB Life 2008, 60, 651-655. [CrossRef] [PubMed]

115. Roy, M.; Li, Z.; Sacks, D.B. IQGAP1 Binds ERK2 and Modulates Its Activity. J. Biol. Chem. 2004, 279, 17329-17337. [CrossRef] [PubMed]

116. DeNicola, G.M.; Karreth, F.A.; Humpton, T.J.; Gopinathan, A.; Wei, C.; Frese, K.; Mangal, D.; Yu, K.H.; Yeo, C.J.; Calhoun, E.S.; et al. Oncogene-induced Nrf2 transcription promotes ROS detoxification and tumorigenesis. Nature 2011, 475, 106-109. [CrossRef] [PubMed]

117. Ghavifekr Fakhr, M.; Farshdousti Hagh, M.; Shanehbandi, D.; Baradaran, B. DNA Methylation Pattern as Important Epigenetic Criterion in Cancer. Genet. Res. Int. 2013, 2013, 1-9. [CrossRef] [PubMed]

118. Esteller, M. CpG island hypermethylation and tumor suppressor genes: A booming present, a brighter future. Oncogene 2002, 21, 5427-5440. [CrossRef] [PubMed]

119. O'Mealey, G.B.; Berry, W.L.; Plafker, S.M. Sulforaphane is a Nrf2-independent inhibitor of mitochondrial fission. Redox Biol. 2017, 11, 103-110. [CrossRef] [PubMed]

120. Rushmore, T.H.; Morton, M.R.; Pickett, C.B. The antioxidant responsive element. Activation by oxidative stress and identification of the DNA consensus sequence required for functional activity. J. Biol. Chem. 1991, 266, 11632-11639. [PubMed]

121. Eggler, A.L.; Luo, Y.; van Breemen, R.B.; Mesecar, A.D. Identification of the Highly Reactive Cysteine 151 in the Chemopreventive Agent-Sensor Keap1 Protein is Method-Dependent. Chem. Res. Toxicol. 2007, 20, 1878-1884. [CrossRef] [PubMed]

122. Hu, C.; Eggler, A.L.; Mesecar, A.D.; van Breemen, R.B. Modification of Keap1 Cysteine Residues by Sulforaphane. Chem. Res. Toxicol. 2011, 24, 515-521. [CrossRef] [PubMed]

123. Thimmulappa, R.K.; Mai, K.H.; Srisuma, S.; Kensler, T.W.; Yamamoto, M.; Biswal, S. Identification of Nrf2-regulated genes induced by the chemopreventive agent sulforaphane by oligonucleotide microarray. Cancer Res. 2002, 62, 5196-5203. [PubMed]

124. Keum, Y.-S.; Oo Khor, T.; Lin, W.; Shen, G.; Han Kwon, K.; Barve, A.; Li, W.; Kong, A.-N. Pharmacokinetics and Pharmacodynamics of Broccoli Sprouts on the Suppression of Prostate Cancer in Transgenic Adenocarcinoma of Mouse Prostate (TRAMP) Mice: Implication of Induction of Nrf2, HO-1 and Apoptosis and the Suppression of Akt-dependent Kinase Pathway. Pharm. Res. 2009, 26, 2324-2331. [CrossRef] [PubMed]

125. Khor, T.O.; Hu, R.; Shen, G.; Jeong, W.-S.; Hebbar, V.; Chen, C.; Xu, C.; Nair, S.; Reddy, B.; Chada, K.; et al. Pharmacogenomics of cancer chemopreventive isothiocyanate compound sulforaphane in the intestinal polyps of ApcMin/+ mice. Biopharm. Drug Dispos. 2006, 27, 407-420. [CrossRef] [PubMed]

126. Xu, C.; Huang, M.-T.; Shen, G.; Yuan, X.; Lin, W.; Khor, T.O.; Conney, A.H.; Kong, A.-N.T. Inhibition of 7,12-Dimethylbenz(a)anthracene-Induced Skin Tumorigenesis in C57BL/6 Mice by Sulforaphane Is Mediated by Nuclear Factor E2-Related Factor 2. Cancer Res. 2006, 66, 8293-8296. [CrossRef] [PubMed]

127. Hu, R.; Xu, C.; Shen, G.; Jain, M.; Khor, T.; Gopalkrishnan, A.; Lin, W.; Reddy, B.; Chan, J.; KONG, A. Gene expression profiles induced by cancer chemopreventive isothiocyanate sulforaphane in the liver of C57BL/6J mice and C57BL/6J/Nrf2 $\left(^{-/-}\right)$mice. Cancer Lett. 2006, 243, 170-192. [CrossRef] [PubMed]

128. Hong, B.; Su, Z.; Zhang, C.; Yang, Y.; Guo, Y.; Li, W.; Kong, A.-N.T. Reserpine Inhibit the JB6 P+ Cell Transformation Through Epigenetic Reactivation of Nrf2-Mediated Anti-oxidative Stress Pathway. AAPS J. 2016, 18, 659-669. [CrossRef] [PubMed]

129. Yang, C.-H.; Yen, T.-L.; Hsu, C.-Y.; Thomas, P.-A.; Sheu, J.-R.; Jayakumar, T. Multi-Targeting Andrographolide, a Novel NF-кB Inhibitor, as a Potential Therapeutic Agent for Stroke. Int. J. Mol. Sci. 2017, 18, 1638. [CrossRef] [PubMed] 
130. Yen, T.-L.; Chen, R.-J.; Jayakumar, T.; Lu, W.-J.; Hsieh, C.-Y.; Hsu, M.-J.; Yang, C.-H.; Chang, C.-C.; Lin, Y.-K.; Lin, K.-H.; et al. Andrographolide stimulates p38 mitogen-activated protein kinase-nuclear factor erythroid-2-related factor 2-heme oxygenase 1 signaling in primary cerebral endothelial cells for definite protection against ischemic stroke in rats. Transl. Res. 2016, 170, 57-72. [CrossRef] [PubMed]

131. Kyselova, Z. Toxicological aspects of the use of phenolic compounds in disease prevention. Interdiscip. Toxicol. 2011, 4, 173-183. [CrossRef] [PubMed]

132. Bhakkiyalakshmi, E.; Sireesh, D.; Rajaguru, P.; Paulmurugan, R.; Ramkumar, K.M. The emerging role of redox-sensitive Nrf2-Keap1 pathway in diabetes. Pharmacol. Res. 2015, 91, 104-114. [CrossRef] [PubMed]

133. Barbaro, B.; Toietta, G.; Maggio, R.; Arciello, M.; Tarocchi, M.; Galli, A.; Balsano, C. Effects of the Olive-Derived Polyphenol Oleuropein on Human Health. Int. J. Mol. Sci. 2014, 15, 18508-18524. [CrossRef] [PubMed]

134. Katsiki, M.; Chondrogianni, N.; Chinou, I.; Rivett, A.J.; Gonos, E.S. The Olive Constituent Oleuropein Exhibits Proteasome Stimulatory Properties In Vitro and Confers Life Span Extension of Human Embryonic Fibroblasts. Rejuvenation Res. 2007, 10, 157-172. [CrossRef] [PubMed]

135. Huang, L.; Chen, C.H. Proteasome regulators: Activators and inhibitors. Curr. Med. Chem. 2009, 16, $931-939$. [CrossRef] [PubMed]

136. Zhang, Z.-R.; Leung, W.N.; Cheung, H.Y.; Chan, C.W. Osthole: A Review on Its Bioactivities, Pharmacological Properties, and Potential as Alternative Medicine. Evid. Based Complement. Alternat. Med. 2015, 2015, 1-10. [CrossRef] [PubMed]

137. Yang, S.-M.; Chan, Y.-L.; Hua, K.-F.; Chang, J.-M.; Chen, H.-L.; Tsai, Y.-J.; Hsu, Y.-J.; Chao, L.K.; Feng-Ling, Y.; Tsai, Y.-L.; et al. Osthole improves an accelerated focal segmental glomerulosclerosis model in the early stage by activating the Nrf2 antioxidant pathway and subsequently inhibiting NF- $\mathrm{BB}-$ mediated COX-2 expression and apoptosis. Free Radic. Biol. Med. 2014, 73, 260-269. [CrossRef] [PubMed]

138. Bao, Y.; Meng, X.; Liu, F.; Wang, F.; Yang, J.; Wang, H.; Xie, G. Protective effects of osthole against inflammation induced by lipopolysaccharide in BV2 cells. Mol. Med. Rep. 2018, 17. [CrossRef]

139. Chen, Z.; Mao, X.; Liu, A.; Gao, X.; Chen, X.; Ye, M.; Ye, J.; Liu, P.; Xu, S.; Liu, J.; et al. Osthole, a Natural Coumarin Improves Cognitive Impairments and BBB Dysfunction After Transient Global Brain Ischemia in C57 BL/6J Mice: Involvement of Nrf2 Pathway. Neurochem. Res. 2015, 40, 186-194. [CrossRef] [PubMed]

140. Hodges, R.E.; Minich, D.M. Modulation of Metabolic Detoxification Pathways Using Foods and Food-Derived Components: A Scientific Review with Clinical Application. J. Nutr. Metab. 2015, 2015, 760689. [CrossRef] [PubMed]

141. Pietsch, K.; Saul, N.; Chakrabarti, S.; Stürzenbaum, S.R.; Menzel, R.; Steinberg, C.E.W. Hormetins, antioxidants and prooxidants: Defining quercetin-, caffeic acid- and rosmarinic acid-mediated life extension in C. elegans. Biogerontology 2011, 12, 329-347. [CrossRef] [PubMed]

142. Newman, J.C.; Milman, S.; Hashmi, S.K.; Austad, S.N.; Kirkland, J.L.; Halter, J.B.; Barzilai, N. Strategies and Challenges in Clinical Trials Targeting Human Aging. J. Gerontol. Ser. A Biol. Sci. Med. Sci. 2016, 71, 1424-1434. [CrossRef] [PubMed]

143. Takaya, K.; Suzuki, T.; Motohashi, H.; Onodera, K.; Satomi, S.; Kensler, T.W.; Yamamoto, M. Validation of the multiple sensor mechanism of the Keap1-Nrf2 system. Free Radic. Biol. Med. 2012, 53, 817-827. [CrossRef] [PubMed]

144. Tsikas, D.; Hanff, E.; Brunner, G. Spermidine for a Long, Dementia-Free Life? Glob. J. Pharm. Pharm. Sci. 2017, 2. [CrossRef]

145. Minois, N. Molecular Basis of the 'Anti-Aging' Effect of Spermidine and Other Natural Polyamines-A Mini-Review. Gerontology 2014, 60, 319-326. [CrossRef] [PubMed]

146. Eisenberg, T.; Abdellatif, M.; Schroeder, S.; Primessnig, U.; Stekovic, S.; Pendl, T.; Harger, A.; Schipke, J.; Zimmermann, A.; Schmidt, A.; et al. Cardioprotection and lifespan extension by the natural polyamine spermidine. Nat. Med. 2016, 22, 1428-1438. [CrossRef] [PubMed]

147. Eisenberg, T.; Knauer, H.; Schauer, A.; Büttner, S.; Ruckenstuhl, C.; Carmona-Gutierrez, D.; Ring, J.; Schroeder, S.; Magnes, C.; Antonacci, L.; et al. Induction of autophagy by spermidine promotes longevity. Nat. Cell Biol. 2009, 11, 1305-1314. [CrossRef] [PubMed]

148. Yang, Y.; Chen, S.; Zhang, Y.; Lin, X.; Song, Y.; Xue, Z.; Qian, H.; Wang, S.; Wan, G.; Zheng, X.; et al. Induction of autophagy by spermidine is neuroprotective via inhibition of caspase 3-mediated Beclin 1 cleavage. Cell Death Dis. 2017, 8, e2738. [CrossRef] [PubMed] 
149. Anand David, A.; Arulmoli, R.; Parasuraman, S. Overviews of biological importance of quercetin: A bioactive flavonoid. Pharmacogn. Rev. 2016, 10, 84. [CrossRef] [PubMed]

150. Miles, S.L.; McFarland, M.; Niles, R.M. Molecular and physiological actions of quercetin: Need for clinical trials to assess its benefits in human disease. Nutr. Rev. 2014, 72, 720-734. [CrossRef] [PubMed]

151. Belinha, I.; Amorim, M.A.; Rodrigues, P.; de Freitas, V.; Moradas-Ferreira, P.; Mateus, N.; Costa, V. Quercetin Increases Oxidative Stress Resistance and Longevity in Saccharomyces cerevisiae. J. Agric. Food Chem. 2007, 55, 2446-2451. [CrossRef] [PubMed]

152. Kampkötter, A.; Timpel, C.; Zurawski, R.F.; Ruhl, S.; Chovolou, Y.; Proksch, P.; Wätjen, W. Increase of stress resistance and lifespan of Caenorhabditis elegans by quercetin. Comp. Biochem. Physiol. Part B Biochem. Mol. Biol. 2008, 149, 314-323. [CrossRef] [PubMed]

153. Chondrogianni, N.; Kapeta, S.; Chinou, I.; Vassilatou, K.; Papassideri, I.; Gonos, E.S. Anti-ageing and rejuvenating effects of quercetin. Exp. Gerontol. 2010, 45, 763-771. [CrossRef] [PubMed]

154. Granato, M.; Rizzello, C.; Gilardini Montani, M.S.; Cuomo, L.; Vitillo, M.; Santarelli, R.; Gonnella, R.; D'Orazi, G.; Faggioni, A.; Cirone, M. Quercetin induces apoptosis and autophagy in primary effusion lymphoma cells by inhibiting PI3K/AKT/mTOR and STAT3 signaling pathways. J. Nutr. Biochem. 2017, 41, 124-136. [CrossRef] [PubMed]

155. Wang, Y.; Zhang, W.; Lv, Q.; Zhang, J.; Zhu, D. The critical role of quercetin in autophagy and apoptosis in HeLa cells. Tumor Biol. 2016, 37, 925-929. [CrossRef] [PubMed]

156. Qi, P.; He, Z.; Zhang, L.; Fan, Y.; Wang, Z. Rottlerin-induced autophagy leads to apoptosis in bladder cancer cells. Oncol. Lett. 2016, 12, 4577-4583. [CrossRef] [PubMed]

157. Chhiber, N.; Kaur, T.; Singla, S. Rottlerin, a polyphenolic compound from the fruits of Mallotus phillipensis (Lam.) Müll.Arg., impedes oxalate/calcium oxalate induced pathways of oxidative stress in male wistar rats. Phytomedicine 2016, 23, 989-997. [CrossRef] [PubMed]

158. Yin, X.; Zhang, Y.; Su, J.; Hou, Y.; Wang, L.; Ye, X.; Zhao, Z.; Zhou, X.; Li, Y.; Wang, Z. Rottlerin exerts its anti-tumor activity through inhibition of Skp2 in breast cancer cells. Oncotarget 2016, 7, 66512-66524. [CrossRef] [PubMed]

159. Torricelli, C.; Salvadori, S.; Valacchi, G.; Souček, K.; Slabáková, E.; Muscettola, M.; Volpi, N.; Maioli, E. Alternative Pathways of Cancer Cell Death by Rottlerin: Apoptosis versus Autophagy. Evid. Based. Complement. Alternat. Med. 2012, 2012, 980658. [CrossRef] [PubMed]

160. Lin, S.-R.; Fu, Y.-S.; Tsai, M.-J.; Cheng, H.; Weng, C.-F. Natural Compounds from Herbs that can Potentially Execute as Autophagy Inducers for Cancer Therapy. Int. J. Mol. Sci. 2017, 18, 1412. [CrossRef] [PubMed]

161. Singh, B.N.; Kumar, D.; Shankar, S.; Srivastava, R.K. Rottlerin induces autophagy which leads to apoptotic cell death through inhibition of PI3K/Akt/mTOR pathway in human pancreatic cancer stem cells. Biochem. Pharmacol. 2012, 84, 1154-1163. [CrossRef] [PubMed]

162. Kumar, D.; Shankar, S.; Srivastava, R.K. Rottlerin induces autophagy and apoptosis in prostate cancer stem cells via PI3K/Akt/mTOR signaling pathway. Cancer Lett. 2014, 343, 179-189. [CrossRef] [PubMed]

163. Hemshekhar, M.; Sebastin Santhosh, M.; Kemparaju, K.; Girish, K.S. Emerging Roles of Anacardic Acid and Its Derivatives: A Pharmacological Overview. Basic Clin. Pharmacol. Toxicol. 2012, 110, 122-132. [CrossRef] [PubMed]

164. Wu, Y.; He, L.; Zhang, L.; Chen, J.; Yi, Z.; Zhang, J.; Liu, M.; Pang, X. Anacardic Acid (6-Pentadecylsalicylic Acid) Inhibits Tumor Angiogenesis by Targeting Src/FAK/Rho GTPases Signaling Pathway. J. Pharmacol. Exp. Ther. 2011, 339, 403-411. [CrossRef] [PubMed]

165. Seong, Y.-A.; Shin, P.-G.; Yoon, J.-S.; Yadunandam, A.K.; Kim, G.-D. Induction of the Endoplasmic Reticulum Stress and Autophagy in Human Lung Carcinoma A549 Cells by Anacardic Acid. Cell Biochem. Biophys. 2014, 68, 369-377. [CrossRef] [PubMed]

166. Wink, M. Annual Plant Reviews, Biochemistry of Plant Secondary Metabolism; John Wiley \& Sons, Inc.: Hoboken, NJ, USA, 2009; ISBN 9781405183970.

167. Neef, D.W.; Jaeger, A.M.; Thiele, D.J. Heat shock transcription factor 1 as a therapeutic target in neurodegenerative diseases. Nat. Rev. Drug Discov. 2011, 10, 930-944. [CrossRef] [PubMed]

(C) 2018 by the authors. Licensee MDPI, Basel, Switzerland. This article is an open access article distributed under the terms and conditions of the Creative Commons Attribution (CC BY) license (http:/ / creativecommons.org/licenses/by/4.0/). 